\title{
The economics and gender factor in soya bean production and profitability in Kenya: a case of smallholder farms in Western Kenya
}

\section{Dave Nyongesa*}

Kenya Agricultural and Livestock Research Organization (KALRO), Food Crops Research Institute,

Kabete Research Centre,

Socio-Economics and Policy Development Unit, P.O. Box 14733-00800 (Westlands), Nairobi, Kenya

Email: Dave.Nyongesa@kalro.org

*Corresponding author

\section{Robert B. Mabele}

University of Dar es Salaam,

College of Social Sciences (CoSS),

School of Economics,

P.O. Box 35045,

Dares Salaam, Tanzania

Email: rmabelle@udsm.ac.tz

\section{Anthony O. Esilaba}

Kenya Agricultural and Livestock Research Organization (KALRO), Natural Resource Systems Sub Unit, P.O. Box 57811-00200 (City Square),

Nairobi, Kenya

Email: anthony.esilaba@kalro.org

Email: aesilaba@gmail.com

\section{Christine K. Mutoni}

Karatina University,

Faculty of Applied Sciences,

Department of Biochemistry,

P.O. Box 1957-10101,

Karatina, Kenya

Email: kanee02@yahoo.com

\begin{abstract}
Soya-bean is among world's major crops, cultivated for its high oil, proteins content and its ability in soil-fertility amendments. The study assessed the determinants, constraints and profitability/gross-margins of soya-bean production in Western Kenya. Multistage sampling technique and field surveys were used in data-collection process covering 370 households. Regression,
\end{abstract}


gender, profitability and gross-margins were the analyses done. Results indicated gross-margins of soya-bean production within the study sites differed significantly from zero (KES 13,401-20,545); it was profitable because net profits ranged from KES $9243-13,548$ for 2010. All gender-cadres shared in soya-bean production activities $(5.0-18.0 \%)$. The mean technical-, allocativeand economic-efficiencies obtained were $0.78,65$ and 0.59 respectively. Smallholders/farmers' economic-inefficiencies arose from many negativelysigned and statistically significant factors/coefficients with $p$-values of 0.0000 0.0240 . Increased use of these factors and county governments and other stakeholders' interventions would positively impact smallholders' efficiency resulting into higher output and profitability.

Keywords: gender; cost; soya-bean production; profitability/gross-margins; Western Kenya; smallholder(s); interviewees; marketing; technical efficiency; allocative-efficiency; economic-efficiency; stochastic-frontier.

Reference to this paper should be made as follows: Nyongesa, D., Mabele, R.B., Esilaba, A.O. and Mutoni, C.K. (2017) 'The economics and gender factor in soya bean production and profitability in Kenya: a case of smallholder farms in Western Kenya', Int. J. Agricultural Resources, Governance and Ecology, Vol. 13, No. 3, pp.211-240.

Biographical notes: Dave Nyongesa holds a PhD in Economics and works at KALRO Food Crops Research Institute, KALRO Kabete Research Centre in the Socioeconomics and Policy Development Unit. He is a Principal Research Officer who has research experience of $>20$ years. He underwent gender training for three years (2004-2006). He is KALRO's Coordinator for Gender, Social and Participatory Methods. He serves as ASARECA's Gender Focal Person for Kenya/KALRO. He has implemented many projects in gender mainstreaming, participatory methods, commodity value-chains and HIV/AIDS. Currently he is implementing Kenya Cereals Enhancement \& Climate Resilient Agricultural Livelihoods KCEP-CRAL Programme in 13 counties in Kenya.

Robert B. Mabele holds a PhD (University of Dar es Salaam), MSc Agric-Econ (University of Tennessee) and BA (Hons) (University of Eastern Africa). $\mathrm{He}$ has been serving as a professor since 1987 and teaching economics/research units since 1974 in the University of Dar es salaam (UDSM) where he works. $\mathrm{He}$ has held several positions within UDSM: Director Economic Research Bureau (ERB) (1988-1993); Senior Research Fellow (1976-1987); Director, (1976-1982); Acting Director, (Dec. 1975-Jul. 1976); Research Fellow, (Aug 1975-Jun 1976); Assistant Research Fellow, (Aug. 1973-Jun. 1975); Assistant Resident Tutor (Apr. 1970-Aug. 1983). He is widely published.

Anthony O. Esilaba is a Soil Scientist, Senior Principal Research Scientist and Assistant Director and Head of the Natural Resources Sub-Unit at the Kenya Agricultural \& Livestock Research Organization (KALRO) Secretariat in Nairobi, Kenya. His responsibilities include the national coordination of the planning, programming, coordination and execution of research programmes in five sub-programmes that include soil and water management, integrated soil fertility management, land use planning, environment and climate change and irrigation, drainage and management of problem soils. He has more than 30 years' research experience and various publications (peer refereed journal papers and book chapters).

Christine K. Mutoni is an assistant part-time lecturer at the Universities of Karatina and Chuka, Kenya. She holds a BSc in Biochemistry (Egerton) and an MSc in Biochemistry (Biotechnology) from Jomo Kenyatta University of 
Agriculture and Technology (JKUAT) and she has registered for $\mathrm{PhD}$ (JKUAT) in the same field commencing in September 2017. Her interest is in crops biotechnology and socioeconomic research. She worked as an assistant researcher under Dr. Dave Nyongesa in implementing various donor funded projects for two years before proceeding for her postgraduate studies in 2008 and resumed her position in January 2013 to December 2015.

\section{Introduction}

\subsection{Agricultural sector}

Agriculture forms a significant portion of the economies of all African countries and it contributes towards major continental priorities. These include; eradicating poverty and hunger, boosting intra-Africa trade and investments, rapid industrialisation and economic diversification, sustainable resource and environmental management, and creating jobs, human security, and shared prosperity (NEPAD, 2013). Farming is mostly carried out by small-scale farmers (smallholders). There are some 500 million smallholder farms worldwide and more than 2 billion people depend on them for their livelihoods. These small-scale farms produce about $80 \%$ of the food consumed in Asia and sub-Saharan Africa (FAO, 2014). In Kenya, agriculture is the mainstay of the economy because about $80 \%$ (35million) of the population relies on it for employment and livelihood and $70 \%$ of marketed agricultural production. The sector, too, contributes about $30 \%$ of Kenya's gross domestic product (GDP) (Koskei et al., 2013). In addition to influencing the overall economic performance through its contribution to the GDP, agriculture contributes about $40 \%$ of government revenue, more than $60 \%$ of the total export revenue and provides food for the country (Koskei et al., 2013). Soya bean production presents a great potential for improving livelihoods of the resource-constrained smallholders and it grows well with limited fertilisers because it fixes nitrogen (N) (Chianu et al., 2009) which boosts production of associated cereals and its market value and demands are high. Participation in commercialised agriculture of cash/food crops such as soya bean can improve the livelihoods of many smallholders through employment and enhanced household incomes (GoK, 2010).

\subsection{Soya bean production and marketing}

Soya bean (Glycine max.) is one of the world's major crops and has been cultivated by man for nearly 5000 years because of its agronomic and nutritional value (Collombet, 2013). Less than seven decades ago, soya bean plant was considered an obscure crop whose cultivation was a domain of the Far East. However, it has established an important foothold in the world today. It is presently the world's most important grain legume in terms of total production, international trade, and a source of income (FAO, 2014). It has been cultivated for its high oil, proteins content and for its ability in increasing soil fertility through biological $\mathrm{N}$-fixation by bacteria resident in soya bean roots nodules (Onyibe et al., 2006). It is an important legume crop in the world, a leading source of edible oils flavour, calcium, iron and vitamins (Chianu et al., 2008). It is a prominent source of protein for animals and an alternative (most often to fishmeal) source of fats and energy to poultry, and pigs (Chianu et al., 2008). It is the cheapest and most readily 
available source of protein, an alternative substitute to animal protein especially in developing countries, a major future source of dietary protein in Africa (Idrisa et al., 2010 ). It accounts for approximately $60 \%$ of vegetable protein and $30 \%$ oil supply in the world. Soya bean seeds contain $40 \%$ protein and $20 \%$ each of oil and carbohydrate (Chianu et al., 2006). It is a multipurpose crop whose importance ranges from its use in soymilk production, oil processing, livestock feeds, industrial and human consumption, and more recently, as a source of bio-energy (Myaka et al., 2005). It has medical or pharmacological qualities, one of which could be used in fighting the dreaded HIV and AIDS pandemic (Kumar, 2007). Soya bean is also rich in lecithin, which is used in many products as an emulsifying agent (Chianu et al., 2006). Pure soya bean oil is used to blend fats and margarines. It is also used in the manufacture of soaps, paints, resins and plastics.

Presently, soya bean is the third among the four main genetically modified (GM) crops in the world today, the other three being maize, cotton and canola. The GM crops have been modified with bacterium Bacillus thuringiensis and they have been adopted worldwide, being grown by 29 countries with an approximately 182 million hectares planted in 2014 (James, 2014). Soya bean cultivation in Kenya started in 1904 having been introduced from Uganda (Chianu et al., 2006). It is intercropped with other crops or grown as a sole crop by smallholders under rainfed conditions. As an intercrop with cereal crops, it provides a strategy for crop rotation, diversification, food-security and soil-fertility replenishment. In Kenya soya bean grows on a wide range of soils and climatic conditions. It requires $300-1200 \mathrm{~mm}$ of rainfall and an altitude of 0-2200 metres above sea level (a.s.l) to produce high yield. This makes it a droughtresistant crop of great potential in lower midland agro-ecological zones of low midland (LM i.e. LM1-LM4) in Western Kenya (Jaetzold et al., 2006). It requires optimum moisture for germination, in early vegetative stage and during flowering. At altitudes of $>2200 \mathrm{~mm}$ a.s.l, flowering may not occur and the crop remains vegetative (Thagana and Riungu, 2000). Although climate and variety differences in soya beans are the most critical determinants for soya bean farming, it is apparent that the climate in Western Kenya favours its production. The availability of appropriate seed varieties and their viability are other important determinants in the soya bean production in the study sites. Research results have shown that soya beans were well adapted for production in all agro-ecological zones of Western Kenya and incorporating its residues in the soil helped to maintain soil fertility. It has an enormous potential to improve the declining soil fertility of many maize-based farming systems in Western Kenya due to its ability in atmospheric N-fixation ability (Chianu et al., 2009). Soya bean forms a common component of the farming systems in Western Kenya where smallholders intercrop it with maize, sorghum, finger millet, cassava or sugarcane (Rachier, 2001).

Given the importance of soya bean, its historical background and the geographical potential, it would be expected that Kenya by now should be self-sufficient in the production and marketing of the crop. However, soya bean production in Kenya was low and was estimated at 4335 metric tonnes (MT) accounting for around $0.7 \%$ of world production (FAO, 2011). Soya bean has remained a minor and an obscure crop in cropping systems of Kenya, while its consumption has been constantly growing forcing the country to import thousands of MT that increased from 50,000 MT in 2008 to 120,000 MT in 2011 (Collombet, 2013). Succeeding with the demand side options, requires smallholder soya bean producers and processors to participate in supply chains for added value products with growing markets (Keane, 2008). This meant finding ways to participate in the type of managed supply chains, which were developing, in a manner 
that was efficient and compatible with local development processes occurring in specific communities. This called for consideration of an entire soya bean value chain approach in Western Kenya.

This paper reports on production and profitability segments of the soya bean valuechain. The objectives of this study were to: (1) examine the determinants and constraints of soya bean production in Western Kenya; (2) assess profitability and gross-margins of soya bean production in the study sites under two cropping systems (sole and intercrop) and in two seasons (long and short rains) respectively. Three hypotheses were tested; Ho: (i). Soya bean production in Western Kenya was not profitable; (ii). The soya bean producers in Western Kenya were technically and allocatively inefficient; (iii). Soya bean producers' socio-economic features in Western Kenya did not influence the technical and allocative efficiencies.

\section{Methodology}

\subsection{Description of the study sites}

The study was undertaken in Kakamega and Busia Counties of Western Kenya. Western Kenya was chosen because it produces $90 \%$ of the total soya bean produced in Kenya (Tinsley, 2009). Kakamega County borders counties; Vihiga to the south, Siaya to the west, Bungoma to the north and Nandi to the east. Kakamega has 12 sub-counties and 24 administrative divisions. It lies between latitude $0^{\circ}$ and $16^{\prime} 58^{\prime}$ ' north and longitude $34^{\circ}$ $45^{\prime}$ '" east and covers an area of $3050.3 \mathrm{Km}^{2}$. The altitudes of county range from 1240 2000 metres above sea level and has two main ecological zones, the Upper Medium (UM) and the Lower Medium (LM). The county received high rainfall (almost all year round) ranging from 1280.1-2214.1 $\mathrm{mm}$ in 2011. The rainfall pattern was evenly distributed all year. March and July received heavy rains while December and February received light rains. The temperatures ranged from $18-29^{\circ} \mathrm{C}$. The early months of the year and November were the hottest months. The county had an average humidity of 67\% (MoDP, 2013).

Busia County is situated at the extreme western border of the country. The county borders the counties of Bungoma to the north, Kakamega to the east and Siaya to the south-west. The county also borders Lake Victoria to the south-east and the Republic of Uganda to the west. The county is divided into seven administrative sub-counties namely Samia, Bunyala, Butula, Busia, Nambale, Teso North and Teso South. These subcounties are further divided into 10 divisions. It lies between latitude $0^{\circ}$ and $0^{\circ} 45^{\prime}$ north and longitude $34^{\circ} 25^{\prime}$ east and covers an area of $1694.5 \mathrm{~km}^{2}$. It received an annual rainfall of 760-2000 $\mathrm{mm}$ in 2011 . The county experienced two rain seasons, the longrains (LR) season, which was its peak between late March and May and the short-rains (SR) that occurred between August and October. The dry season with scattered rains occurred from December-February. The annual mean maximum temperatures ranged from $26-30^{\circ} \mathrm{C}$ while the mean minimum temperature ranged from $14-22^{\circ} \mathrm{C}(\mathrm{MoDP}$, 2013).

\subsection{Sampling procedure}

A multi-stage sampling technique (Castillo, 2009) was adopted for this study. The first stage involved a random selection of two counties (Kakamega and Busia) out of four 
counties in Western Kenya. The second stage involved a random selection of four subcounties out of 19 sub-counties in the two selected counties. The third stage involved a random selection of five administrative divisions (Matungu, East Wanga, Shiatsala and Lunza in Kakamega County and Chakol in Busia County, out of 11 in the four selected sub-counties (Mumias, Matungu, Butere and Teso South). The final stage was a random selection of an average of 75 households from each of the five selected administrative divisions.

\subsection{Data collection, data types and data sources}

The data collection took six months from September 2011 to February 2012. The data was collected on the soya bean enterprises for the two rain seasons the LR (March-June) and SR (September-November), and two cropping systems 'sole' (pure stand) and 'intercrop' for the year 2010. The data collected and utilised in this study were of two types, quantitative and qualitative, from both primary and secondary sources. Quantitative data were information about quantities that could be measured and written down with numbers. It could be quantified, verified and was amenable to statistical manipulation. Qualitative data on the other hand was typically descriptive data. It was used mainly on gender issues in addressing the questions: (1) Who does what in soya bean production? (2) Who decides on use of resources and sharing of proceeds? \& (3) Who has control and access over resources? Quantitative data defines whereas qualitative data describes. Primary (principal or first-hand experience) data were collected from soya bean smallholders and other key economic players along the value chain continuum, covering 370 respondents from the two study counties. Data were collected by three well trained enumerators. The enumerators were trained for one week on the content of the questionnaire, which they had to internalise and on skills for the questionnaire administration. Each enumerator administered two questionnaires on average per day (Mondays-Fridays) because a questionnaire took a minimum of three hours to complete depending on the ability of the respondents. Secondary data, which were obtained through literature reviews of reports and publications from the two county governments, research organisations, agricultural colleges and libraries.

The study used questionnaires to collect primary data. Questionnaires were used because they are research instruments, in which a set of formalised questions were typed and printed along with the choice of answers from, which respondents chose the right option. The questionnaire used had a number of sections: socioeconomic and demographic characteristics; inputs; outputs; processing; marketing and utilisation. Each of the sections had three sets of questions (close-ended, attitude and open-ended). Closeended questions were those that the respondents selected an appropriate option from the provided series of answers. Close-ended questions were particularly useful in obtaining numerical factual information about the soya bean enterprises. Attitude questions were asked to find out the respondents' opinions or attitudes to a given situation. A Likert scale that provides a battery of attitude statements was applied to which the respondents said how much they agreed or disagreed with each case. Open-ended questions were used as an adjunct to the main theme of the questionnaire and allowed the respondents to elaborate upon some of the earlier more specific questions. Open-ended questions were inserted at the end of each section of the questionnaire and offered additional 
information. Apart from the open-ended questions, the others were pre-coded because the analysis of the results was carried out using a statistical package. The questions were short, simple and precise but not verbose.

The questionnaire before its use was validated and verified by the authors' Organization's Centre Research and Advisory Committee (CRAC). The CRAC vets proposals and data collection tools prepared by the scientists to ensure that the tools meet the set criteria. The set criteria ensured that the tools were: complete (included all of the data elements and records needed for the engagement and were specific, and organised for the purpose); accurate and timely; consistent (data obtained and used in a manner that was clear and well-defined enough to yield similar results in similar analyses); correct (the data set reflected the data entered at the source and properly represented the intended or computed results); unaltered (data reflected source and had not been tampered with) and could lead to an increase in understanding and decrease in uncertainty. The tool after validation and vetting by CRAC was also pre-tested in one of the sub-counties within Kakamega County which was not among those where the actual data was collected. A pilot survey was undertaken as a preliminary study on 35 respondents, rehearsal to know the time, cost, efforts, reliability of the tool and the data to be collected for use. It was then refined and printed for the actual field work.

The detailed data collected were on socio-demographic characteristics (age, gender, marital status, headship and management, educational levels attained, family-size, farming experience in years and primary occupations of household heads) of soya bean smallholders; farm and production characteristics (total farm-sizes in acres, credit accessed, capita/equipment used, land size under soya bean, crop production systems; farm inputs used, number of farm-sites; farm-enterprises, costs of farm inputs, credit and labour requirements and sources; land tenure, access, ownership and control; constraints to production value addition; quantities processed, marketed and consumed; and sales/returns). The marketing data included the distances to the markets, accessibility, prices offered, marketing channels, market information, marketing constraints and mode of sale; transport costs and location of the markets.

The data collected was cleaned on daily basis by the correspondence author to ensure there were no gaps. In case of any identified gaps or unanswered questions, the responsible enumerator was asked to go back to the respondent for completion of the questionnaire(s) before the enumerator moved to other sites. The cleaned data was then passed to two hired data entry-clerks for inputting it into a spreadsheet package. Prior to the actual analyses of the data, a series of unconditional tests were performed on the entered data to assess the risk related to the intended use of the data. These edits helped determine whether the data was acceptable and if sufficiently reliable. A sufficiently reliable data being that where the likelihood of significant errors or incompleteness is minimal. The tests disclosed whether there were failures of data elements to meet established requirements; range or value limits; presence/absence; proper dates; positive/negative signs; alpha/numeric formats and formula derivations. These tests and the following analytical techniques were performed in Statistical Package for Social Science (SPSS) version 21.

\subsection{Analytical techniques}

The analytical plan applied in this study encompassed: descriptive statistics; gender analysis; the stochastic-frontier function; profitability and gross-margin analyses. 


\subsubsection{Descriptive and gender analyses}

Descriptive statistics such as central tendency (mean, median, mode, frequency distribution, percentages, ranking and measures of dispersion such as range, variance and standard deviation) were computed. A gender analysis examined the differences between women and men, boys and girls in the household, community and economic spheres using systematic sex-disaggregated gathered data to get information on gender differences in the soya bean enterprises (ITC, 2009). These analyses were used to achieve objective (1) of the study.

\subsubsection{The stochastic-frontier function}

The stochastic-frontier model/approach that finds wide acceptance within agricultural economics was used to measure efficiency (technical, allocative and economic). The stochastic-frontier specification was basically based on Cobb-Douglas function and transcendental logarithmic (translog) functions that was specified either as production or cost function (Udoh and Akintola, 2001). The corresponding dual cost frontier was determined from the production frontier. The two frontiers (production and cost) were the basis for deriving farm level efficiency measures. The stochastic production (frontier) function was typically specified as in equation (1):

$$
\ln Y_{i}=\ln \beta_{0}+\sum_{i=1}^{5} \beta_{i} \ln X_{i j}+v_{i}-\mu_{i}
$$

where $\ln =$ the natural logarithm; $Y_{i}=$ farm output $(\mathrm{kg}) ; X_{i j}=$ vector of farm inputs $\left(X_{1}-X_{5}\right)$ used; $X_{1}=$ farm size in acres; $X_{2}=$ quantity of seeds in kilograms $(\mathrm{kg})$; $X_{3}=$ fertiliser in $\mathrm{kg} ; X_{4}=$ total labour used in man-hours and $X_{5}=$ volume of agrochemicals in litres; $v=$ random variability in the production that cannot be influenced by the farmer; $\mu=$ deviation from maximum potential output attributable to technical inefficiency; $\beta_{0}=$ intercept; $\beta_{i}=$ vector of production function parameters to be estimated; $i=1,2,3$, $n$ farms; $j=1,2,3, m$ inputs.

The inefficiency model (technical and allocative) was used to achieve objective (1), it was specified as in equation (2):

$$
\begin{aligned}
U_{i}=\Theta_{0}= & \Theta_{1} z_{1}+\Theta_{2} z_{2}+\Theta_{1} z_{3}+\Theta_{4} z_{4}+\Theta_{5} z_{5}+\Theta_{6} z_{6}+\Theta_{7} z_{7}+\Theta_{8} z_{8}+\Theta_{9} z_{9} \\
& +\Theta_{10} z_{10}
\end{aligned}
$$

where $U_{i}=$ technical inefficiency effect of the $i$-th farm; $Z_{1}=$ educational level of the family head (farmer) in years of formal education completed; $Z_{2}=$ household-size number of persons; $Z_{3}=$ age of household head in years; $Z_{4}=$ farming experience of family head in years; $Z_{5}=$ gender factor i.e. the roles performed and by who?; $Z_{6}=$ amount of credit received in Kenya shillings (KES); $Z_{7}=$ extension services as number of times smallholders were visited per year; $Z_{8}=$ membership of a group or cooperative society; $Z_{9}=$ transport costs; $Z_{10}=$ distance to the soya bean market; $\Theta_{0}=$ constant; $\Theta_{1}-$ $\Theta_{10}=$ parameters estimated.

The allocative efficiency was determined using the cost frontier dual to the production frontier as in equation (3):

$$
\ln C_{i}=\ln \propto 0+\propto i \ln P_{i j}+\varphi \ln \left(Y_{i}^{*}\right)
$$

where $\ln =$ the natural logarithm; $C_{i}$ is the minimum cost to produce output $Y ; P_{i j}$ is a vector of input price, and $\alpha$ is a vector of parameters. 
Hence the stochastic-frontier cost function was expressed as in equation (4):

$$
\ln C_{i}=\beta_{0}+\beta_{1} \ln X_{1}+\beta_{2} \ln X_{2}+\beta_{3} \ln X_{3}+\beta_{4} \ln X_{4}+\beta_{5} \ln X_{5}+\beta_{6} \ln X_{6}+v_{i}+\mu_{i}
$$

where $C_{i}=$ total cost of production in KES/acre; $X_{1}=$ cost of farmland or rent for a year (KES/acre); $X_{2}=$ cost of seed in KES; $X_{3}=$ cost of fertiliser in KES; $X_{4}=$ cost of labour in KES; $X_{5}=$ cost of agrochemical in KES; $X_{6}=$ output of soya bean produced in $\mathrm{kg}$; $\beta_{0}=$ the intercept; $\beta_{1-6}=$ vector of the coefficients for the associated independent variables in the production function; $V_{i}=$ one-sided component, which captures deviation from frontier as a result of inefficiency of the farmer; $\mu_{i}$. $=$ effect of random shocks outside the smallholders' control, observation and measurement error and other stochastic (noise) error term.

Economic efficiency $\left(E E_{i}\right)$ : farm specific $E E_{i}$ was the product of technical and allocative efficiencies. It was estimated using equation (5):

$$
E E_{i}=T E_{i} * A E_{i}
$$

where $E E=$ economic efficiency; $T E=$ technical efficiency; and $A E=$ allocative efficiency. The parameter estimates were obtained using the Maximum Likelihood Estimation (MLE) of estimation.

\subsubsection{Profitability and gross margins analyses}

The profitability and gross-margin analyses in this study were used to achieve objective (2). Profit (P) was a major indicator of viability of any enterprise. The amount of revenue realised and operating cost of an enterprise determined how much gain or loss an enterprise could achieve within a certain period of time. Cost and return analysis usually forms the basis for farm profitability analyses. This involved itemising costs and returns of production that were then used to arrive at such estimates as the return to one unit of resource used in the production. In estimating the level of profitability $(\mathrm{P})$ of soya bean production in the study sites for the 2010 seasons, the total cost of production was deducted from the total revenue realised using equation (6):

$$
P=T R-T C
$$

where $P$ is profit; $T R$ is the total revenue and is captured as the total market value of soya bean produced; $T C$ is the total cost incurred in producing soya bean. The total cost of production takes into account both variable and fixed costs, however, in subsistence farming fixed costs are usually negligible. If $P$ is greater than zero, then soya bean production would be declared profitable and vice versa. A value of zero would indicate a break-even point. The analysis was based on an acre of land through scalar transformation of all individual observations.

Gross-margin analysis (GMA) involved evaluating the efficiency of an individual enterprise so that comparison would be made between enterprises on the farm. It was a very useful tool in situations where fixed capital was a negligible portion of the farming enterprise as was the case in subsistence farming. Gross-margins are widely used in farm planning. They can be used to prepare partial budgets for minor changes in the farm programme, or to prepare completed budgets for major changes in farm programmes. In this study GMA analysis involved determining all variable costs and revenue associated with the soya bean enterprise. The total variable costs (TVCs) were for the two cropping systems (sole and intercropping) and the two rain seasons (LR and SR) for 2010. The 
difference between the total revenues (TR) and TVCs gave the gross profits made by the smallholders. However, to obtain gross-margins i.e. gross profits per acre of soya bean cropland, the gross profit was divided with the total soya bean cropland. The computation used computed means of the three variables to arrive at the gross-margins for the entire sites and that of the separate divisions covered in the study. This was in line with Olorunsanya et al. (2009) that employed cost and return analysis in the economic analysis of soya bean production in Kwara State, north-central Nigeria. The gross-margin analysis was expressed as in equation (7):

$$
G M=G I-T V C
$$

where $\mathrm{GM}=$ gross-margin $(\mathrm{KES}) ; \mathrm{GI}=$ gross income $(\mathrm{KES})$; $\mathrm{TVC}=$ total variable cost (KES).

\section{Results}

\subsection{Socio-demographic characteristics}

The results of 370 interviewees showed that $57 \%$ were males and $43 \%$ females. The average age was 48 years while the minimum and maximum ages were 23 and 84 years respectively. The average household-size was 6 persons. The headship and management of the households were; male-headed and managed (69.7\%), female-headed and managed $(11.6 \%)$, male-headed but female managed $(17.6 \%)$ and child-headed and managed (1.1\%). The majority of the interviewees were peasant smallholders $(80.5 \%)$ while $7.3 \%$ combined peasant farming and operating small business ventures. The remaining $(11.9 \%)$ were involved in other various minor occupations. The majority (62.7\%) of interviewees had a farming experience of $<5$ years; $5-10$ years $(24.9 \%), 11-15$ years $(5.7 \%)$ and the remaining $(6.7 \%)$ over 15 years. The majority of interviewees $(77 \%)$ had undergone farmer training. The majority $(51.9 \%)$ of interviewees had attained primary level, secondary $(31.6 \%)$, tertiary $(5.4 \%)$, university $(0.8 \%)$ while $10.3 \%$ had no formal education.

\subsection{Farm characteristics}

The mean land-size was three (3) acres while family members owned an average of 1.2 acres. In terms of land access, ownership and decision-making on land use, $83.5 \%$ had access and $70.5 \%$ had control. The majority of decisions $(60 \%)$ were made by husbands; wives $(14.1 \%)$, both spouses $(24.3 \%)$ and children (1.6\%). On average (45\%) hired land of which $53.6 \%$ hired one acre each. Soya bean was grown by smallholders on land sizes as follows; quarter of an acre or less $(30.3 \%)$ half acre $(32.0 \%)$, one acre (23.0\%) and the rest was one acre and above, where one farmer grew four acres per season. Soya bean was grown under two cropping systems; intercrop $(50.8 \%)$ and sole (pure) stand (34.1\%) while $15.1 \%$ is a combination of the two systems. It was also grown in two seasons; LR (March-June) and SR (September-November).

\subsection{Soya bean production process}

Soya bean production involved several activities that included: land preparation, planting, fertiliser application, weeding, agrochemical application, harvesting, transport of produce, threshing and winnowing, grading, packaging and storage, and marketing. 
Table 1 summarises the type of worker who performed the different activities. Soya bean in the study sites was grown either as sole (pure) stand or intercropped with other crops during the two seasons (Table 2). Figures 1 and 2 are pictures of the two cropping systems respectively. Three main equipment (means) were used in land preparation; oxen, hand and tractor in both LR and SR seasons. The use of oxen dominated $71.8 \%$ (LR) and 69.7\% (SR); hand 24.1\% (LR) and 26.9\% (SR); tractor $4.0 \%$ (LR) and 3.4\% (SR). Labour used in this activity was from three main sources; hired (52.0\%), own $(44.0 \%)$, and a combination of the two $(4.0 \%)$. Table 3 presents the three main sources of soya bean seeds used by smallholders under the two seasons and cropping systems in the study sites. Although soya bean is known for soil amendment, it was found that smallholders in the study sites applied various fertilisers: Diamonium phosphate (DAP); Mono-ammonium phosphate (MAP); Nitrogen phosphorous potassium (NPK), Single superphosphate (SSP); Triple superphosphate (TSP) and Farm yard manure (FYM) in the soya bean production under the two cropping systems. Table 4 summarises the type of fertilisers purchased and used during the two cropping systems.

Table 1 Soya bean production activities by gender

\begin{tabular}{|c|c|c|c|c|c|c|c|c|c|}
\hline \multicolumn{2}{|c|}{ Activity ( $\&$ \& valid \%) } & \multirow{2}{*}{$\begin{array}{c}\text { Men } \\
244\end{array}$} & \multirow{2}{*}{$\frac{\text { Women }}{31}$} & \multirow{2}{*}{$\begin{array}{c}\text { Children } \\
3\end{array}$} & \multirow{2}{*}{$\begin{array}{c}\begin{array}{c}\text { Men \& } \\
\text { women }\end{array} \\
60\end{array}$} & \multirow{2}{*}{$\begin{array}{c}\text { Men \& } \\
\text { children }\end{array}$} & \multirow{2}{*}{$\begin{array}{c}\begin{array}{c}\text { Women \& } \\
\text { children }\end{array} \\
9\end{array}$} & \multirow{2}{*}{$\begin{array}{c}\text { All } \\
22\end{array}$} & \multirow{2}{*}{$\begin{array}{r}\text { Total } \\
370\end{array}$} \\
\hline & $\mathrm{n}$ & & & & & & & & \\
\hline Land preparation & $\%$ & 65.9 & 8.4 & 0.8 & 16.3 & 0.3 & 2.4 & 5.9 & 100 \\
\hline \multirow{2}{*}{ Planting } & $\mathrm{n}$ & 50 & 73 & 1 & 161 & 3 & 27 & 55 & 370 \\
\hline & $\%$ & 13.5 & 19.7 & 0.3 & 43.5 & 0.8 & 7.3 & 14.9 & 100 \\
\hline \multirow{2}{*}{$\begin{array}{l}\text { Fertiliser } \\
\text { application }\end{array}$} & $\mathrm{n}$ & 42 & 24 & 7 & 40 & 1 & 3 & 16 & 133 \\
\hline & $\%$ & 31.6 & 18.0 & 5.3 & 30.1 & 0.8 & 2.3 & 12.0 & 100 \\
\hline \multirow{2}{*}{ Weeding 1} & $\mathrm{n}$ & 63 & 119 & 1 & 122 & 1 & 24 & 40 & 370 \\
\hline & $\%$ & 17.0 & 32.2 & 0.3 & 33.0 & 0.3 & 6.5 & 10.8 & 100 \\
\hline \multirow{2}{*}{ Weeding 2} & $\mathrm{n}$ & 64 & 121 & 1 & 118 & 1 & 24 & 41 & 370 \\
\hline & $\%$ & 17.3 & 32.7 & 0.3 & 31.9 & 0.3 & 6.5 & 11.1 & 100 \\
\hline \multirow{2}{*}{ Harvesting } & $\mathrm{n}$ & 35 & 73 & 0 & 151 & 5 & 38 & 68 & 370 \\
\hline & $\%$ & 9.5 & 19.7 & 0 & 40.8 & 1.4 & 10.3 & 18.4 & 100 \\
\hline \multirow{2}{*}{$\begin{array}{l}\text { Produce } \\
\text { transporting }\end{array}$} & $\mathrm{n}$ & 81 & 50 & 19 & 77 & 3 & 15 & 44 & 289 \\
\hline & $\%$ & 28.0 & 17.3 & 6.6 & 26.6 & 1.0 & 5.2 & 15.2 & 100 \\
\hline \multirow{2}{*}{$\begin{array}{l}\text { Threshing \& } \\
\text { Winnowing }\end{array}$} & $\mathrm{n}$ & 42 & 159 & 7 & 79 & 4 & 31 & 48 & 370 \\
\hline & $\%$ & 11.4 & 43.1 & 1.9 & 21.4 & 1.1 & 8.4 & 13.0 & 100 \\
\hline \multirow{2}{*}{ Storage } & $\mathrm{n}$ & 11 & 79 & 164 & 7 & 60 & 1 & 48 & 370 \\
\hline & $\%$ & 3 & 21.3 & 44.3 & 1.9 & 16.2 & 0.3 & $13 . .0$ & 100 \\
\hline \multirow{2}{*}{$\begin{array}{l}\text { Grading \& } \\
\text { Packaging }\end{array}$} & $\mathrm{n}$ & 94 & 45 & 166 & 33 & 4 & 10 & 18 & 370 \\
\hline & $\%$ & 25.4 & 12.2 & 44.9 & 8.9 & 1.0 & 2.7 & 4.9 & 100 \\
\hline \multirow{2}{*}{ Marketing } & $\mathrm{n}$ & 80 & 60 & 20 & 60 & 15 & 5 & 30 & 270 \\
\hline & $\%$ & 29.6 & 22.2 & 7.4 & 22.2 & 5.6 & 1.9 & 11.1 & 100 \\
\hline
\end{tabular}

Source: Field survey 2011/2012; Notes: \% = valid per cent; $n=$ sample size involved, "All"= men, women and children 
Table 2 Crop(s) intercropped with soya bean during LR and SR seasons

\begin{tabular}{lcccc}
\hline \multirow{2}{*}{ Intercrops } & \multicolumn{2}{c}{ Freq. $(n)$} & \multicolumn{2}{c}{ Per cent (\%) } \\
\cline { 2 - 5 } & LR & SR & LR & SR \\
\hline Soya bean/maize & 160 & 184 & 43.2 & 49.7 \\
Soya bean/sugarcane & 16 & 37 & 4.3 & 10.0 \\
Soya bean/maize \& sugarcane & 2 & 3 & 0.5 & 0.8 \\
Soya bean/sorghum & 1 & 2 & 0.3 & 0.5 \\
Soya bean/cotton & 1 & & 0.3 & \\
Soya bean/pineapple & 1 & 1 & 0.3 & 0.3 \\
Soya bean/millet & & 1 & & 0.3 \\
Soya bean/groundnuts & & 1 & & 0.3 \\
Soya bean/green grams & & 2 & & 0.8 \\
Soya bean/cassava & & 2 & & 0.5 \\
Total & 181 & 233 & 48.9 & 63.0 \\
Missing System & 189 & 137 & 51.1 & 37.0 \\
Total & 370 & 370 & 100 & 100 \\
\hline
\end{tabular}

Source: Field survey 2011/2012; Notes: Freq. = frequency; LR= long rains; $\mathrm{SR}=$ short rains.

Table 3 Sources of seeds grown during the LR and SR under the sole and intercrop systems

\begin{tabular}{lcccccccc}
\hline & \multicolumn{4}{c}{ Sole } & \multicolumn{5}{c}{ Intercrop } \\
\cline { 2 - 9 } Source of seed & \multicolumn{2}{c}{ Freq. $(n)$} & \multicolumn{2}{c}{ Valid \% } & \multicolumn{2}{c}{ Freq. $(n)$} & \multicolumn{2}{c}{ Valid \% } \\
\cline { 2 - 9 } & $L R$ & $S R$ & $L R$ & $S R$ & $L R$ & $S R$ & $L R$ & $S R$ \\
\hline Recycled & 81 & 113 & 46.3 & 95.0 & 101 & 221 & 55.8 & 94.8 \\
Purchased & 92 & 6 & 52.6 & 5.0 & 80 & 11 & 44.2 & 4.7 \\
Recycled \& purchased & 2 & & 1.1 & & & 1 & & 0.4 \\
Total & 175 & 119 & 100 & 100 & 181 & 233 & 100 & 100 \\
Missing System & 195 & 251 & & & 189 & 137 & & \\
Total & 370 & 370 & & & 370 & 370 & & \\
\hline
\end{tabular}

Source: Field survey 2011/2012; Notes: $\mathrm{LR}=$ long rains; $\mathrm{SR}=$ short rains.

Table 4 Type of the fertiliser bought and used under sole and intercrop systems during LR and SR seasons

\begin{tabular}{lcccccccc}
\hline & \multicolumn{4}{c}{ Sole } & \multicolumn{5}{c}{ Intercrop } \\
\cline { 2 - 9 } Fertiliser type & \multicolumn{2}{c}{ Freq. $(n)$} & \multicolumn{2}{c}{ Valid $\%$} & \multicolumn{2}{c}{ Freq. $(n)$} & \multicolumn{2}{c}{ Valid \% } \\
\cline { 2 - 9 } & $L R$ & $S R$ & $L R$ & $S R$ & LR & SR & LR & $S R$ \\
\hline None & 12 & 66 & 6.5 & 35.7 & 64 & 9 & 26.3 & 3.7 \\
DAP & 102 & 80 & 55.1 & 43.2 & 79 & 122 & 32.5 & 50.4 \\
MAP & 3 & 1 & 1.6 & 0.5 & 5 & 4 & 2.1 & 1.7 \\
TSP & 6 & 2 & 3.2 & 1.1 & 10 & 12 & 4.1 & 5.0 \\
SSP & 26 & 13 & 14.1 & 7.0 & 23 & 37 & 9.5 & 15.3 \\
NPK & 1 & 1 & 0.5 & 0.5 & 2 & 3 & 0.8 & 1.2 \\
FYM & 31 & 22 & 16.8 & 11.9 & 59 & 52 & 24.3 & 21.5 \\
DAP \& FYM & 4 & & 2.2 & & 1 & 3 & 0.4 & 1.2 \\
\hline
\end{tabular}


Table 4 Type of the fertiliser bought and used under sole and intercrop systems during LR and SR seasons (continued)

\begin{tabular}{lcccccccc}
\hline & \multicolumn{4}{c}{ Sole } & \multicolumn{5}{c}{ Intercrop } \\
\cline { 2 - 9 } Fertiliser type & \multicolumn{2}{c}{ Freq. $(n)$} & \multicolumn{2}{c}{ Valid \% } & \multicolumn{2}{c}{ Freq. $(n)$} & \multicolumn{2}{c}{ Valid \% } \\
\cline { 2 - 9 } & LR & $S R$ & LR & $S R$ & LR & SR & LR & $S R$ \\
\hline Total & 185 & 185 & 100 & 100 & 243 & 242 & 100 & 100.0 \\
Missing System & 185 & 185 & & & 127 & 128 & & \\
Total & 370 & 370 & & & 370 & 370 & & \\
\hline
\end{tabular}

Source: Field survey 2011/2012; Notes: $\mathrm{LR}=$ long rains; $\mathrm{SR}=$ short rains; FYM= farm yard manure; $\mathrm{DAP}=$ Diamonium phosphate; $\mathrm{MAP}=$ Mono-ammonium phosphate; NPK = Nitrogen phosphorous potassium; $\mathrm{SSP}=$ Single superphosphate; TSP $=$ Triple superphosphate.

Figure 1 Soya bean grown under sole cropping system in Chakol sub-county

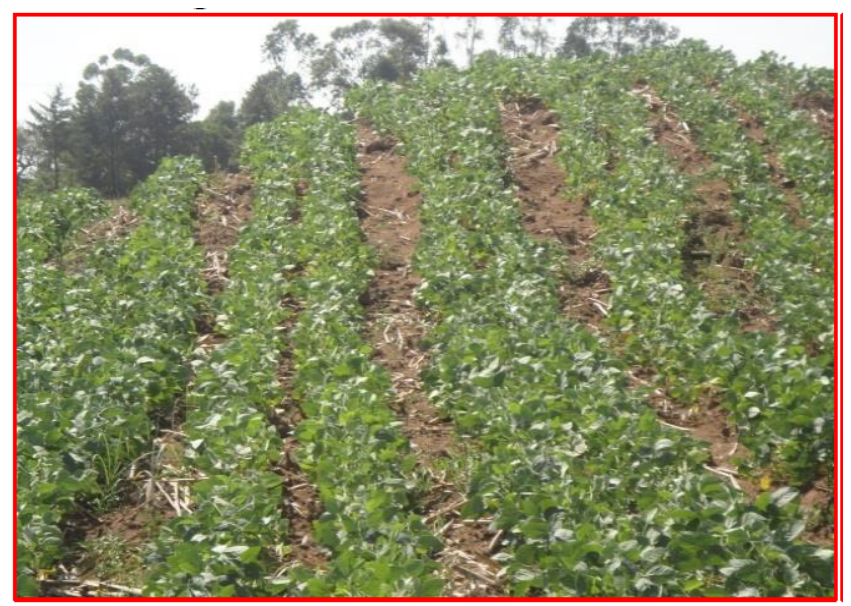

Figure 2 Two rows of soya bean intercropped with maize in Matungu sub-county

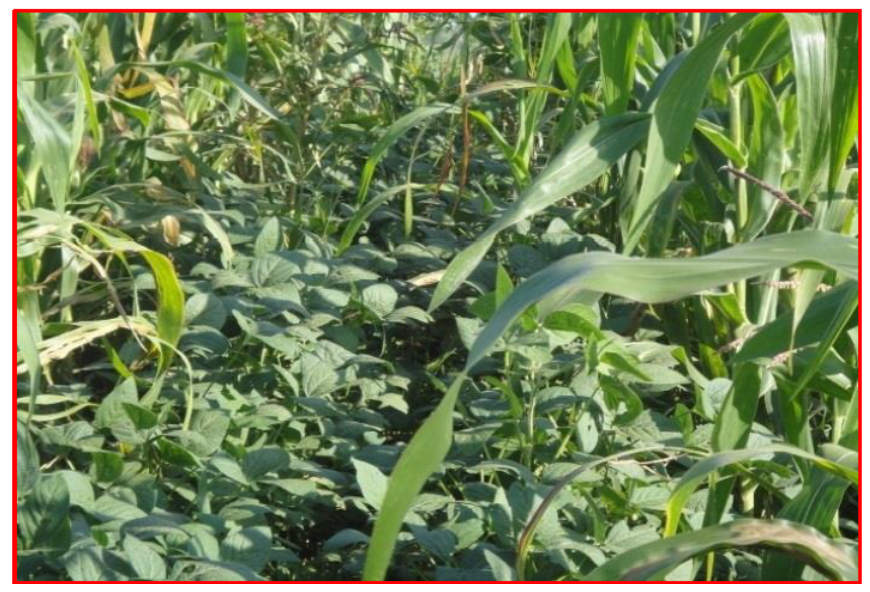




\subsection{Constraints to soya bean production}

Smallholders in the study sites identified 11 constraints (that could be grouped as; socioeconomic, natural and agronomic) they faced in soya bean production. Constraints were what the smallholders viewed as hindrances to their soya bean production activities within the study sites. Figure 3 presents the constraints faced by smallholders, ranging from the highest to the lowest $(55-0.3 \%)$.

Figure 3 Constraints identified

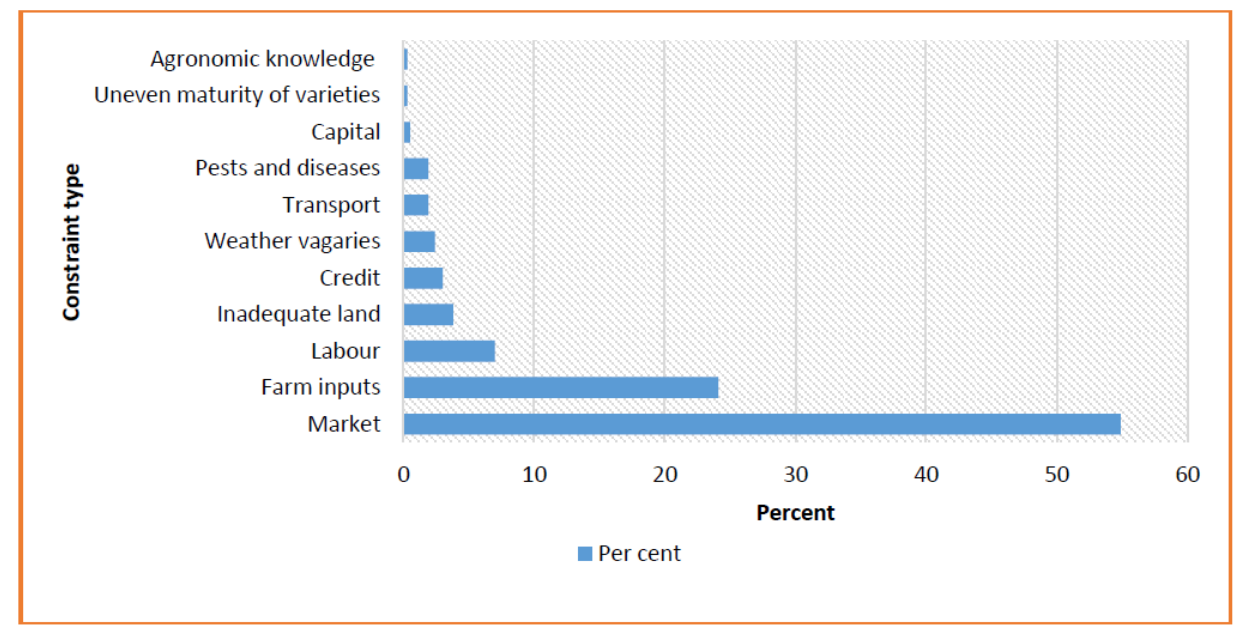

\subsection{Measurement of efficiencies}

The efficiencies were measured using the results from stochastic-frontier function to determine technical (T), allocative (A) and economic (E) efficiencies (Es) respectively. Table 5 summarises the results of the TE and inefficiency of the soya bean producers in the study sites. The estimated parameters were; farm-size/land (0.62), seeds (0.07), fertiliser (0.06) and agrochemical (0.25) and labour (0.19), all were positively signed and statistically significant (except fertiliser and labour) at either $1 \%, 5 \%$ or $10 \%$. Table 6 , presents the AE of the soya bean producers in the study sites. The estimated parameters for the stochastic-frontier cost function were; farm-size/land $(0.14)$, seeds $(0.31)$, fertiliser (0.17) and agrochemical (0.35), labour (0.16) and soya bean output (0.15), all were positively signed and statistically significant at the three levels of confidence. Table 7 presents the estimated parameters for the economic stochastic-frontier for the soya bean producers in the study sites. The parameters were; farm-size/land $(0.07)$, seeds $(0.02)$, fertiliser (0.01) and agrochemical (0.07) and labour (0.04), all were positively signed and statistically significant (except fertiliser) at the three levels of confidence. The descriptive statistics for the overall distribution of efficiencies i.e. TE, AE and $\mathrm{EE}$ of soya bean interviewees in the study sites are presented in Table 8. The statistics were as follows; maximum: (0.882, 0.898 and 0.862); minimum: $(0.106,0.099$ and 0.020$)$; mean: $(0.778$, 0.646 and 0.588 ) respectively. Figure 4 shows the efficiency groups ranging from $0.0-0.10$ and depicts the extent of the three types of efficiencies for the 370 interviewees covered in the study sites. 
Table 5 Technical efficiency of soya bean producers in the sites

\begin{tabular}{|c|c|c|c|c|}
\hline Variables & Parameter & Coefficients & t-ratio & $p$-values \\
\hline CONSTANT $\left(\beta_{\mathrm{o}}\right)$ & $\beta_{\mathrm{o}}$ & 11.2136 & $13.809 * * *$ & 0.0000 \\
\hline FRMLNDSZ $\left(\mathrm{X}_{1}\right)$ & $\beta_{1}$ & 0.6196 & $5.142 * * *$ & 0.0000 \\
\hline QTYSEEDS $\left(\mathrm{X}_{2}\right)$ & $\beta_{2}$ & 0.0724 & $1.986^{* *}$ & 0.0239 \\
\hline QTYFERTS $\left(\mathrm{X}_{3}\right)$ & $\beta_{3}$ & 0.0646 & 0.668 & 0.2523 \\
\hline UDLABOUR $\left(\mathrm{X}_{4}\right)$ & $\beta_{4}$ & -0.1888 & $-1.586^{*}$ & 0.0569 \\
\hline QTYAGRCH $\left(\mathrm{X}_{5}\right)$ & $\beta_{5}$ & -0.2492 & $-4.619 * * *$ & 0.0000 \\
\hline \multicolumn{5}{|l|}{ Inefficiency Model } \\
\hline CONSTANT $\left(\Theta_{0}\right)$ & $\Theta_{0}$ & -8.1832 & 1.3333 & 0.0916 \\
\hline $\operatorname{EDCTNLVL}\left(Z_{1}\right)$ & $\Theta_{1}$ & -0.6776 & $-1.726^{* *}$ & 0.0426 \\
\hline $\operatorname{HHSIZE}\left(Z_{2}\right)$ & $\Theta_{2}$ & -0.6866 & $-1.926 * *$ & 0.0274 \\
\hline $\operatorname{AGE}\left(Z_{3}\right)$ & $\Theta_{3}$ & -0.5236 & $-1.450^{*}$ & 0.0740 \\
\hline FRMNGEXP $\left(Z_{4}\right)$ & $\Theta_{4}$ & -0.6842 & $-1.782 * *$ & 0.0378 \\
\hline GENDERFA $\left(Z_{5}\right)$ & $\Theta_{5}$ & -0.6943 & $-1.847^{* *}$ & 0.0328 \\
\hline $\operatorname{CREDIT}\left(Z_{6}\right)$ & $\Theta_{6}$ & -0.6824 & $-1.764^{* *}$ & 0.0393 \\
\hline EXTNSERS $\left(Z_{7}\right)$ & $\Theta_{7}$ & -0.5634 & $-1.797 * *$ & 0.0366 \\
\hline $\operatorname{MEMBRSHP}\left(Z_{8}\right)$ & $\Theta_{8}$ & -0.0742 & -0.652 & 0.2574 \\
\hline TRPTCSTS $\left(Z_{9}\right)$ & $\Theta_{9}$ & -0.3186 & $-1.649 * *$ & 0.0499 \\
\hline DISTMKTS $\left(Z_{10}\right)$ & $\Theta_{10}$ & -0.5433 & $-1.786^{* *}$ & 0.0375 \\
\hline \multicolumn{5}{|l|}{ Variances } \\
\hline SIGMA-SQUARED & $\sigma^{2}$ & 26.8374 & $1.740 * *$ & 0.0414 \\
\hline GAMMA & $Y$ & 0.9642 & $126.221^{* * *}$ & 0.0000 \\
\hline LOG LIKELIHOOD FN & & -164.7254 & & \\
\hline LR TEST & $\chi^{2}$ & 52.6830 & & \\
\hline NO. RESTRICTIONS & & 11.00 & & \\
\hline
\end{tabular}

Source: Field survey $2011 / 2012 ; n=370$; Likelihood $=-164.73 * * * ; * * *$ significant at $1 \%(p<0.01)$ level of significance (Los), ** significant at $5 \%(p<0.05)$ Los, *significant at $10 \% \quad(p<0.10)$; Notes: QTY = quantity; FRMLNDSZ = Farmland/size; QTYFERTS = quantity of fertiliser; QTYAGRCH = quantity of agrichemicals; EDCTNLVL $=$ education level; HHSIZE $=$ household size; FRMNGEXP = farming experience; GENDERFA = gender factor; EXTSERVS = extension services; MEMBRSHP = membership; TRPTCSTS = transport costs; DISTMKTS $=$ distance to markets; UDLABOUR $=$ Used labour. 
Table 6 Allocative efficiency of soya bean producers in the sites

\begin{tabular}{|c|c|c|c|c|}
\hline Variables & Parameter & Coefficients & t-ratio & $p$-values \\
\hline CONSTANT $\left(\beta_{\mathrm{o}}\right)$ & $\beta_{0}$ & 4.5733 & $4.8630 * * *$ & 0.0000 \\
\hline COFRMLND $\left(\mathrm{X}_{1}\right)$ & $\beta_{1}$ & 0.1379 & $4.2066^{* * *}$ & 0.0000 \\
\hline $\operatorname{COSEEDS}\left(\mathrm{X}_{2}\right)$ & $\beta_{2}$ & 0.3128 & $1.9677 * *$ & 0.0249 \\
\hline COFERTS $\left(\mathrm{X}_{3}\right)$ & $\beta_{3}$ & 0.1714 & $1.6944 * *$ & 0.0455 \\
\hline COLABOUR $\left(\mathrm{X}_{4}\right)$ & $\beta_{4}$ & 0.1652 & $6.0248 * * *$ & 0.0000 \\
\hline COAGRCHE $\left(\mathrm{X}_{5}\right)$ & $\beta_{5}$ & 0.3545 & $3.6440 * * *$ & 0.0002 \\
\hline RDOUTPUT $\left(\mathrm{X}_{6}\right)$ & $\beta_{6}$ & 0.1478 & $1.8449 * *$ & 0.0329 \\
\hline \multicolumn{5}{|l|}{ INEFFICIENCY MODEL } \\
\hline CONSTANT $\left(\Theta_{0}\right)$ & $\Theta_{0}$ & -16.7592 & -0.9528 & 0.1709 \\
\hline $\operatorname{EDCTNLVL~}\left(Z_{1}\right)$ & $\Theta_{1}$ & -0.0362 & $-7.1456^{* * *}$ & 0.0000 \\
\hline $\operatorname{HHSIZE}\left(Z_{2}\right)$ & $\Theta_{2}$ & -0.1946 & $-3.2251 * * *$ & 0.0007 \\
\hline $\operatorname{AGE}\left(Z_{3}\right)$ & $\Theta_{3}$ & -0.8756 & -0.7582 & 0.2245 \\
\hline $\operatorname{FRMNGEXP~}\left(Z_{4}\right)$ & $\Theta_{4}$ & -0.1203 & $-3.4587 * * *$ & 0.0003 \\
\hline $\operatorname{GENDERFA}\left(Z_{5}\right)$ & $\Theta_{5}$ & -0.1986 & $-3.5876^{* * *}$ & 0.0002 \\
\hline $\operatorname{CREDIT}\left(Z_{6}\right)$ & $\Theta_{6}$ & -0.0062 & 0.0046 & 0.4982 \\
\hline $\operatorname{EXTNSERS~}\left(Z_{7}\right)$ & $\Theta_{7}$ & -0.1962 & $-3.5864 * * *$ & 0.0002 \\
\hline $\operatorname{MEMBRSHP}\left(Z_{8}\right)$ & $\Theta_{8}$ & -0.4236 & -0.9810 & 0.1636 \\
\hline TRPTCSTS $\left(Z_{9}\right)$ & $\Theta_{9}$ & -0.4324 & $-5.5624 * * *$ & 0.0000 \\
\hline DISTMKTS $\left(Z_{10}\right)$ & $\Theta_{10}$ & -0.3654 & $-.3 .8845^{* * *}$ & 0.0006 \\
\hline \multicolumn{5}{|l|}{ VARIANCES } \\
\hline SIGMA-SQUARED & $\sigma^{2}$ & 7.2547 & 1.1397 & 0.1276 \\
\hline GAMMA & $Y$ & 0.9456 & $17.5463 * * *$ & 0.0000 \\
\hline LOG LIKELIHOOD FN & & -98.8064 & & \\
\hline LR TEST & $\chi^{2}$ & 8.6656 & & \\
\hline NO. RESTRICTIONS & & 11.00 & & \\
\hline
\end{tabular}

Source: Field survey $2011 / 2012 ; n=370 ;$ Likelihood $=-98.81 * * * ; * * *$ significant at $1 \%(\mathrm{p}<0.01)$ level of significance (Los), $* *$ significant at $5 \%(\mathrm{p}<0.05)$ Los, *significant at $10 \%(p<0.10)$; Notes: $\mathrm{CO}=$ cost; COFRMLND= Farmland size; COFERTS $=$ cost of fertilisers; COAGRCHM $=$ agrichemical; EDCTNLVL $=$ education level; HHSIZE = household size; FRMNGEXP= farming experience; GENDERFA= gender factor; EXTSERVS= extension services; MEMBRSHP= membership; TRPTCSTS $=$ transport costs; DISTMKTS $=$ distance to markets; RDOUTPUT $=$ Realised output; COLABOUR $=$ Cost of labour. 
Table 7 Economic efficiency of soya bean producers in the sites

\begin{tabular}{|c|c|c|c|c|}
\hline Variables & Parameter & Coefficients & $t$-ratio & $p$-values \\
\hline CONSTANT $\left(\beta_{\mathrm{o}}\right)$ & $\beta_{0}$ & 32.3746 & $46.8264 * * *$ & 0.0000 \\
\hline FRMLNDSZ $\left(\mathrm{X}_{1}\right)$ & $\beta_{1}$ & 0.0741 & $14.6984 * * *$ & 0.0000 \\
\hline $\operatorname{SEEDS}\left(\mathrm{X}_{2}\right)$ & $\beta_{2}$ & 0.0168 & $4.6712 * * *$ & 0.0000 \\
\hline FERTS $\left(\mathrm{X}_{3}\right)$ & $\beta_{3}$ & 0.0086 & 0.9682 & 0.1668 \\
\hline LABOUR $\left(\mathrm{X}_{4}\right)$ & $\beta_{4}$ & -0.0446 & $9.8244 * * *$ & 0.0000 \\
\hline $\operatorname{AGROCHEM~}\left(\mathrm{X}_{5}\right)$ & $\beta_{5}$ & -0.0682 & $8.6248 * * *$ & 0.0000 \\
\hline \multicolumn{5}{|l|}{ INEFFICIENCY MODEL } \\
\hline CONSTANT $\left(\Theta_{0}\right)$ & $\Theta_{0}$ & -128.6648 & -1.1326 & 0.1292 \\
\hline $\operatorname{EDCTNLVL~}\left(Z_{1}\right)$ & $\Theta_{1}$ & -0.0082 & $-11.2047 * * *$ & 0.0000 \\
\hline $\operatorname{HHSIZE}\left(Z_{2}\right)$ & $\Theta_{2}$ & -0.1235 & $-9.4275 * * *$ & 0.0000 \\
\hline $\operatorname{AGE}\left(Z_{3}\right)$ & $\Theta_{3}$ & -0.0398 & -1.2810 & 0.1005 \\
\hline $\operatorname{FRMNGEXP~}\left(Z_{4}\right)$ & $\Theta_{4}$ & -0.0332 & $-44.7742 * * *$ & 0.0000 \\
\hline $\operatorname{GENDERFA}\left(Z_{5}\right)$ & $\Theta_{5}$ & -0.0376 & $-47.9932 * * *$ & 0.0000 \\
\hline $\operatorname{CREDIT}\left(Z_{6}\right)$ & $\Theta_{6}$ & -0.0036 & $-1.9894 * *$ & 0.0237 \\
\hline $\operatorname{EXTNSERS~}\left(Z_{7}\right)$ & $\Theta_{7}$ & -0.0042 & $-1.9664 * *$ & 0.0250 \\
\hline $\operatorname{MEMBRSHP}\left(Z_{8}\right)$ & $\Theta_{8}$ & -0.0028 & -0.6430 & 0.2603 \\
\hline TRPTCSTS $\left(Z_{9}\right)$ & $\Theta_{9}$ & -0.0041 & $-1.9662 * *$ & 0.0250 \\
\hline DISTMKTS $\left(Z_{10}\right)$ & $\Theta_{10}$ & -0.0028 & $-1.9844 * *$ & 0.0240 \\
\hline \multicolumn{5}{|l|}{ VARIANCES } \\
\hline SIGMA-SQUARED & $a^{2}$ & 148.3242 & $1.9626^{* *}$ & 0.0252 \\
\hline GAMMA & $Y$ & 0.9186 & $2486.8390 * * *$ & 0.0000 \\
\hline LOG LIKELIHOOD FN & & $-15,700.65$ & & \\
\hline LR TEST & $\chi^{2}$ & 466.87 & & \\
\hline NO. RESTRICTIONS & & 11.00 & & \\
\hline
\end{tabular}

Source: Field survey 2011/2012; $n=370$; likelihood $=-157,00.65 * * * ; * *$ significant at $1 \%(p<0.01)$ level of significance (Los); $* *$ significant at $5 \%(\mathrm{p}<0.05)$ Los, *significant at $10 \% \quad(p<0.10)$; Notes: FRMLNDSZ $=$ Farmland size; AGROCHEM= agrichemical; EDCTNLVL = education level; HHSIZE= household size; FRMNGEXP = farming experience; GENDERFA= gender factor; EXTSERVS = extension services; MEMBRSHP= membership; TRPTCSTS $=$ transport costs; DISTMKTS $=$ distance to markets; FERTS = fertilisers. 
Table 8 Distribution of efficiencies and descriptive statistics

\begin{tabular}{ccccccc}
\hline \multirow{2}{*}{ Efficiency groups/Ranges } & \multicolumn{3}{c}{$T E$} & \multicolumn{2}{c}{$A E$} & \multicolumn{3}{c}{ EE } \\
\cline { 2 - 8 } & Feq. & $\%$ & Feq. & $\%$ & Feq. & $\%$ \\
\hline $0.0-0.20$ & 152 & 41.1 & 52 & 14.1 & 273 & 73.8 \\
$0.21-0.40$ & 76 & 20.5 & 131 & 35.4 & 66 & 17.8 \\
$0.41-0.60$ & 59 & 15.9 & 76 & 20.5 & 21 & 5.7 \\
$0.61-0.80$ & 48 & 13.0 & 66 & 17.8 & 7 & 1.9 \\
$0.81-0.10$ & 35 & 9.5 & 45 & 12.2 & 3 & 0.8 \\
\hline Total & 370 & 100.0 & 370 & 100.0 & 370 & 100.0 \\
\hline Maximum & \multicolumn{2}{c}{0.882} & \multicolumn{2}{c}{0.898} & \multicolumn{2}{c}{0.862} \\
Minimum & \multicolumn{2}{c}{0.106} & \multicolumn{2}{c}{0.099} & 0.020 \\
Mean & \multicolumn{2}{c}{0.778} & 0.646 & \multicolumn{2}{c}{0.588} \\
\hline
\end{tabular}

Source: Field survey 2011/2012; Notes: TE= technical efficiency; AE= allocative efficiency; $\mathrm{EE}=$ economic efficiency; Freq. $=$ frequency and $\%=$ per cent.

Figure 4 Grouped distribution of efficiencies

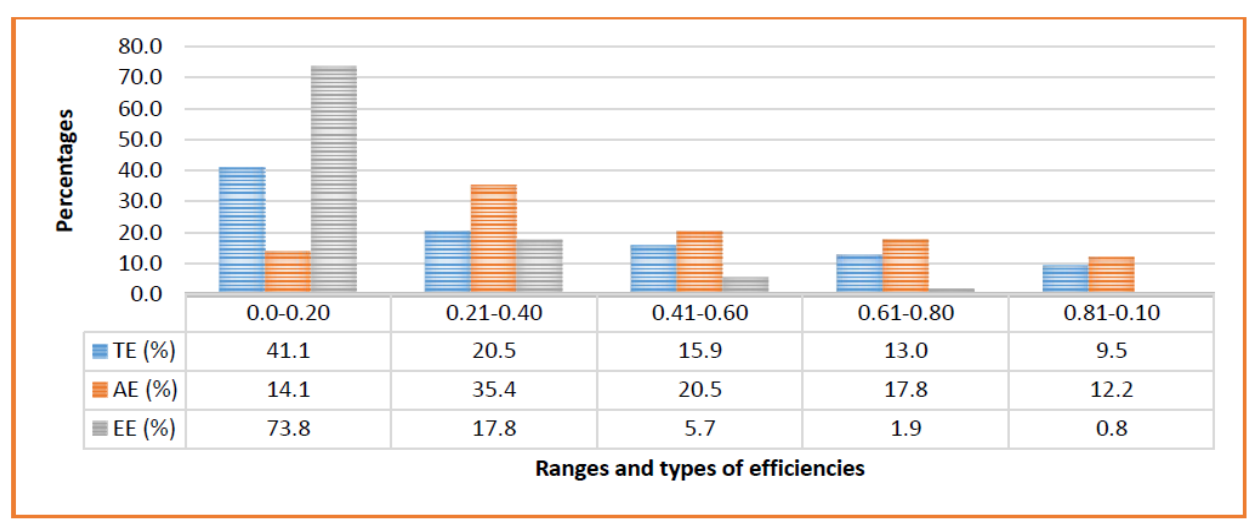

Source: Field survey 2011/2012; Notes: TE= technical efficiency; AE= allocative efficiency; $\mathrm{EE}=$ economic efficiency.

\subsection{Profitability and gross-margin analyses of soya bean production}

The sustainability of any enterprise was normally indicated by the level of profit realised at any given per period of time. Profit was the difference between the total revenue realised from sale of produce and the total costs incurred in producing the produce. If the revenue was higher than the costs then that was profit and the contrary was a loss incurred. The profitability and gross-margin analyses were used to achieve objective 2 and are presented in Table 9. The multiple responses given by interviewees on soya bean profitability are depicted Figure 5. The profitability from soya bean enterprise had made the smallholders resolve in increasing both cropland in acres and yield in kilograms $(\mathrm{kg})$ by computed means of $0.7823(0.02626)$ and 232.5420 (6.67302) respectively. The figures in parenthesis were standard errors. The cropland was to be increased from $0.13-3.75$ acres and yield from $50-650 \mathrm{~kg}$. 
The economics and gender factor in soya bean production

Table 9 Comparative soya bean profitability and gross-margins analyses

\begin{tabular}{lccccccc}
\hline \multirow{2}{*}{ Variables } & \multirow{2}{*}{ All sites } & \multicolumn{5}{c}{ Divisions/Sub counties } \\
\cline { 4 - 8 } & & & E. Wanga & Matungu & Lunza & Shiatsala & Chakol \\
\hline \multirow{2}{*}{$\begin{array}{l}\text { Total Revenue } \\
\text { (TR) }\end{array}$} & Mean & $20,357.70$ & $23,166.95$ & $25,342.40$ & $18,829.20$ & $15,678.40$ & $19,347.00$ \\
& S. E. & 524.20 & 1379.80 & 1301.80 & 1093.10 & 647.70 & 1017.70 \\
& S. Dev & $10,083.30$ & $11,869.60$ & $10,969.30$ & 9715.65 & 5793.40 & 8268.10 \\
Total variable & Mean & 9950.30 & $11,481.40$ & $11,794.15$ & 9112.00 & 7799.30 & $10,103.20$ \\
cost (TVC) & S. E. & 302.20 & 818.50 & 688.00 & 714.70 & 396.60 & 579.00 \\
& S. Dev & 5812.30 & 7041.10 & 5797.05 & 6352.70 & 3547.40 & 4704.10 \\
\hline \multirow{2}{*}{ Total cropland in } & Mean & 0.6144 & 0.6882 & 0.7742 & 0.5729 & 0.3835 & 0.6894 \\
acres & S. E. & 0.219 & 0.0502 & 0.0475 & 0.0510 & 0.0330 & 0.0504 \\
& S. Dev & 0.422 & 0.4319 & 0.4002 & 0.5632 & 0.2948 & 0.4092 \\
\hline Profitability & & $10,407.40$ & $11,685.60$ & $13,548.30$ & 9717.20 & 7879.10 & 9243.20 \\
GM/acre & & $16,939.10$ & $16,979.90$ & $17,499.70$ & $16,961.40$ & $20,545.20$ & $13,401.20$ \\
GM/ Ha & $42,347.75$ & $42,449.75$ & $43,749.25$ & $42,403.50$ & $51,363.00$ & $33,503.00$ \\
\hline Source: & & &
\end{tabular}

Source: Field survey 2011/2012; Notes: SE= standard error; S.Dev =standard deviation.

Figure 5 Reasons given by smallholders on the benefits/profitability of soya bean production

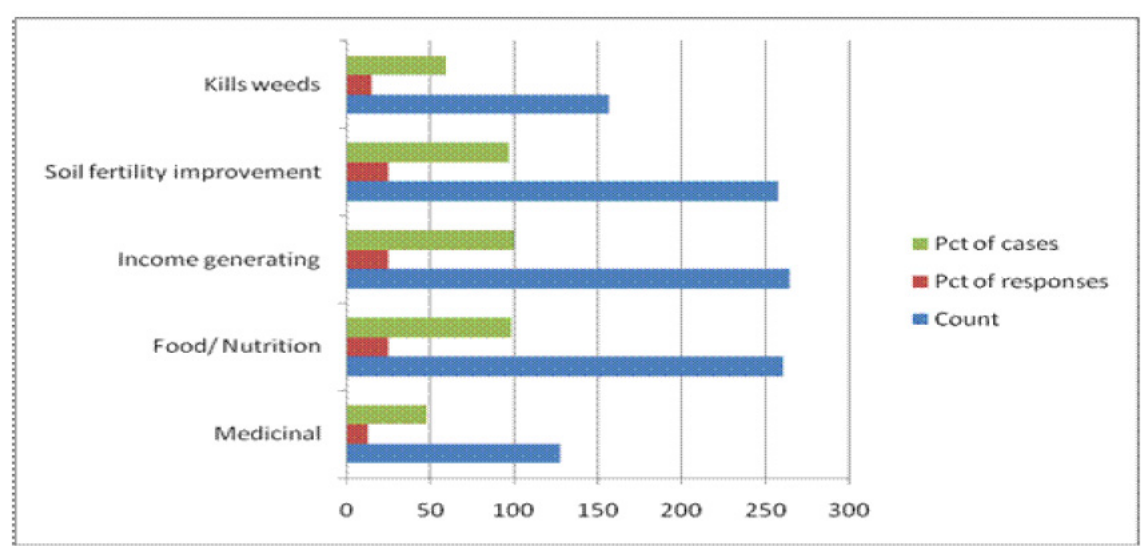

Source: Field survey 2011/2012; Notes; Pct. = percentage.

\section{Discussion}

\subsection{Socio-demographic characteristics}

The majority of soya bean smallholders in the study sites were relatively young. Soya bean production in the study sites had a bright future because most of these relatively young smallholders may continue cultivating the crop for at least other three decades, if they can be motivated to remain in its cultivation. On average, farming experience of the interviewees ranged from 5 to 20 years. Age had a significant influence on decision 
making process of smallholders with respect to risk aversion, adoption of improved agricultural technologies and other production-related decisions. This concurs with Adeola et al. (2011) who showed that young people tended to withstand stress, put more time in agricultural operations that could translate into increased output. Education and training in farming as the study found out influenced adoption of technologies. This concurs with Ahmadu (2011) who showed that education played an important role in agricultural development. It was an essential socio-economic factor, which influenced farmer's decision because it has effect on the awareness, perception, reception and quick adoption of productivity increasing innovations.

\subsection{Farm and production characteristics}

A major characteristic among of small-scale farming in Western Kenya was fragmented land holding. The study found that size of a farmland cultivated was a function of total land available, population pressure, household size and financial resources at a household disposal. This again is in tandem with the findings of Ahmadu (2011) on import of socioeconomic factors in farm production. Credit acquired by a famer increased smallholders' liquidity, to purchase farm inputs and hire labour. Membership of a group or cooperative society provided means of interaction among smallholders that enhanced diffusion of innovations among members. It accorded the smallholders the opportunities of sharing information on modern agricultural production practices. This was in tandem with Ragasa and Golan (2012), which showed that rural groups or cooperatives were an essential avenue for promoting rural development and sustainable rural livelihoods.

\subsection{Soya bean production process}

Soya bean production in the study sites underwent through a number of stages: land preparation, planting and fertiliser application, weeding, agrochemical application, harvesting, transport of produce, threshing and winnowing, storage, grading, packaging and marketing.

\subsubsection{Land Preparation}

Smallholders in the study sites indicated that they prepared their land twice a year, during the LR (March-June) and the SR (September-November). They used three modes of land preparation depending on the resources at their disposal. Smallholders with small pieces of land, normally below one-quarter of an acre, used either hand or oxen. While those with bigger portions of land used oxen or tractors. Land preparation involved two stages: land breaking and repeat/harrowing. The land for those smallholders that grew soya bean under intercrop especially in sugarcane, the ploughing and re-ploughing was normally done by Mumias Sugar Company located within the study sites. The company also planted the sugarcane for them so the smallholders took advantage of this by planting soya bean between the sugarcane rows. Different workers by gender were involved in this activity (Table 1). Among the three ways of soya bean cropland preparation in the two seasons, oxen dominated because oxen were readily affordable to most smallholders but not all and that was why a substantial number of interviewees used hand. Fewer smallholders used tractor compared to oxen and hand because it was expensive and small 
tracts of land under soya bean made its use uneconomical. Family labour was also a problem and that is why the majority of smallholders used hired labour.

\subsubsection{Planting and fertiliser application}

Soya bean planting was normally done twice a year. Smallholders planted soya bean seeds by hand or oxen. Tunnels were dug manually or by oxen. Normally a minimum of three people were involved in this activity. The $1^{\text {st }}$ person dug tunnels, the $2^{\text {nd }}$ put basal fertiliser and returned a thin layer of soil to cover the fertiliser. The $3^{\text {rd }}$ person finally dropped soya bean seeds into the tunnels and covered them with a thin layer of soil, leaving the seeds to germinate. In case of manure being used, the smallholders themselves or employed farm hands to spread manure in the farm before the ploughing and re-ploughing were done. This activity was performed by all the gender cadres (Table1) who were either members of households or hired from other households. Smallholders in the study sites grew a number of soya bean (SB) varieties that included; SB19, SB3, SB25, SB23, SB17, SB24, SB20 and minor ones such as; SB73, SB90 and SB3600 in their order of importance. The first two were the most popular among smallholders. These seeds grown in both seasons (Table 3) were either self-preserved (recycled) or purchased certified seeds from resource centres, seed companies, retail shops, agrovets, neighbours, farmer groups, KALRO (KARI) Njoro, Bukura agricultural college and open markets.

\subsubsection{Weeding, harvesting and transporting the harvest}

Soya bean weeding was normally done twice per season. The first weeding occurred after three weeks to one month following the germination. The second weeding occurred after the second month but before the end of the third month. Smallholders that applied topdressing fertilisers (urea or CAN) added this fertiliser during the second weeding. Different genders were involved in the weeding (Table 1). The labour used in the two weedings came from four different sources (own households, hired, group members and friends). Soya bean of the first season (LR) was normally harvested in the months of May and June. However, for those that planted late, say towards the end of March and April, the harvesting occurred in the month of July. Harvesting was done by hand. The number of harvesters depended on the size of soya bean cropland. On average five people were involved in harvesting one acre per day. The harvest for the second season (SR) was normally done in November and December. Soya bean stalks holding the pods were normally cut off at about 50 centimetres from the top of the soya bean plant, gathered into polythene bags, on wheel barrows or oxen carts. Soya bean once harvested was carried to the homesteads. Although different members of the family normally participated in this activity, it was mainly the domain of men and women. The different worker types by gender (either owned or hired) were involved in harvesting and transporting the soya bean produce (Table 1). The soya bean produce was sun dried at the homesteads for some sometime before it was threshed and winnowed.

\subsubsection{Threshing and winnowing}

Threshing and winnowing were hand done. It was normally done by women and children, however, in certain cases men also assisted. The labour source was both owned 
and hired. The harvested soy stalks after being well dried were put into polythene bags. The mouths of bags were tightly tied. The threshing was done using a stick to pound the bags till all the soya bean seeds were removed from their pods, though some seeds got broken due to pounding process. Winnowing was a process applied in separating the soya bean seeds from the chaff. Wind was used to blow aside the chaff leaving the seeds intact because they were heavy. The seeds were then stacked into polythene bags for storage awaiting packaging and grading or sorting process. Different worker types by gender were involved in these activities (Table 1).

\subsubsection{Storage, grading, packaging and marketing}

Storage activity was performed by all the family members. This activity followed the threshing and winnowing activity. The soya beans once threshed and winnowed were graded and weighed in $90 \mathrm{~kg}$ polythene bags, whose mouths were stitched or tightly tied and stored in a store, granary or one of the main house bedrooms. The grading and packaging activity was very involving because it required the farmer separating the entire broken; pest-damaged and fossilised or spoiled soya beans from the good ones. It involved selecting soya beans of the same size and putting them together, Different worker types by gender were involved in executing these three activities. The marketing followed the storage, grading and packaging. Soya bean was mainly sold to soya bean resource centres in the study sites, some of which had processing plants (Mumias District Federation of Soybean Smallholders; Butere Soya Cooperative Society and the Muungano Development Gateways), open markets, schools and hospitals. Different worker types by gender were involved in this activity (Table 1).

\subsection{Production constraints}

Soya bean growing in Western Kenya faced a number of production constraints that were identified by interviewees in the study sites. The responses to the question; what was the most limiting constraint in soya bean production? Yielded different responses (Figure 3). Market access was identified as the most limiting constraint and this concurs with Bekabil (2015) and Lubungu et al. (2013), which showed that access to local markets was the main constraint in many developing countries in the tropics and sub-tropics where local soya bean production could improve farmer incomes and the sustainability of the production system.

\subsection{Efficiencies measurements}

\subsubsection{Technical efficiency}

Table 5 gives the variance coefficients, a gamma $(Y)$ statistic of 0.9642 , implying that $96 \%$ of the changes in the output could be attributed to smallholders' inefficiency factors. There were technical-inefficiency effects in soya bean production in the study sites. This notwithstanding, the hypothesis that the estimated $\mathrm{Y}=0$ (soya bean production is not profitable) was strongly rejected. The significant level of the $\mathrm{Y}$ indicated the presence of one-sided error term component $\left(v_{i}\right)$ in the specified model (equation 4). Due to the presence of this one-sided error component, the traditional response function estimated by the ordinary least squares (OLS) could not represent the data adequately. Thus, the 
stochastic-frontier function estimated by the maximum likelihood estimation (MLE) procedure was best fitted for the data. Therefore, the second null hypothesis, which specified that the inefficiency effects were not stochastic (producers were technically and allocatively inefficient), was also rejected. The positive and significant (5\%) coefficient of the Sigma-squared $\left(\sigma^{2}\right)$ indicated the correctness of the specified assumption of the distribution of the $v_{i}$. The generalised likelihood ratio statistic was -164.73 , which exceeded the critical LR test (chi-square i.e. $\left.\chi^{2}\right)$ ) value at $1 \%$ level of significance with number of restriction (degree of freedom i.e. df.) of 11 (Table 5).

The factors of production (land, labour, amount of seed, fertiliser, and agrochemicals) used all impacted efficiency of soya bean production either positively or negatively as per the estimated coefficients, which were all significant at either $1(p<0.01), 5(p<0.05)$ or $10(p<0.10) \%$ levels of significance as per the $t$-ratios and $p$-values (Table 5$)$. The parameter for farm-size was 0.62 , significant at $1 \%$ probability level and indicated the relevance of farm-size in soya bean production within the study areas. An increase of $1 \%$ in the size of soya bean cropland led to an increase in output of soya bean by $0.62 \mathrm{~kg}$. The bigger the farm-size the higher the output realised that could be attributed to adoption of agricultural innovations. Doss (2006) recognised that one way of improving agricultural productivity, in particular and rural-livelihoods in general, was through the introduction and adoption of improved agricultural technologies to and by smallholders for improved farm productivity. The amount of seed and fertiliser used had positive effects on soya bean production. The quantity of seed used was significant in soya bean production at $5 \%$ probability level but that of fertiliser was not significant. Fertiliser was not significant possibly due to the soil amending nature of soya beans in fixing nitrogen from the atmosphere. The coefficients of seeds and fertiliser quantities used positively affected output. A $1 \%$ increase in amount of seeds used translated into $0.07 \mathrm{~kg}$ (Table 5) of soya bean produced while the positive coefficient of fertiliser used indicated that as the quantity of fertiliser used increased, yield supposedly also increased. The labour and quantity of agrochemicals used both had negative coefficients. The negative signs implied that as labour used in soya bean production increased, quantity of soya bean produced decreased consummately. Similarly, as the quantity of agrochemicals used in soya bean production increased by a litre, the soya bean produced decreased consummately. However, the negative sign of agrochemicals was unexpected because chemicals were supposed to ameliorate the situation in farming operations (Table 5).

Among the inefficiency model coefficients, the negative coefficient for education level, which was statistically significant at $5 \%$ probability level in the study sites (Table 5), implied that education was an important variable and facilitated adoption of agricultural innovations. Interviewees with greater years of schooling were more efficient in soya bean production because as schooling increased, technical-inefficiency tended to reduce. Considerable education acquired made a farmer to be effective in making informed decisions in agricultural enterprises. Technical-inefficiency tended to decrease by 0.68 as schooling years rose by $1 \%$ (Table 5 ). Both household-size and age estimated coefficients had negative signs (Table 5) indicating that there were inverse-relationships between variables and technical-efficiency. Larger household-sizes were more technically-efficient than those with fewer numbers of people because large numbers translated into cheaper and available family labour that reduced the cost of soya bean production. Age, too, had negative effect on the technical-inefficiency of the soya bean smallholders implying a positive effect on technical-efficiency. A $1 \%$ increase in age of the household-head led to a decrease of $0.52 \%$ in the technical-inefficiency. The positive 
effect of age on technical-efficiency indicated that the responsive and active competence of the interviewees contributed to soya bean production within the study sites. The young and energetic smallholders engaged in soya bean production within the study sites increased its output translating into improved livelihoods. The coefficients of farmingexperience and gender-factor were negatively signed and significant at $5 \%$ (Table 5) level of confidence demonstrating the relevance of accumulating farming-experience and considering gender-issues in the soya bean production. This implied that interviewees with higher farming-experience were more technically-efficient in soya bean production. Farming-experience and gender-factor enhanced the interviewees' skills that translated into smallholders' increased efficiency.

The estimated parameters for credit, extension-services and membership were negatively signed. Of the three variables, the first and second were both statistically significant at $5 \%$ probability level while membership to groups/cooperative society was not statistically significant (Table 5). However, these variables being negatively signed meant that they had had negative-effects on technical-inefficiency because an increase in the use of these factors led to a decline in technical-inefficiency. Credit and extensionservices were important because they enhanced capacity to acquire production inputs (credit) on time and improved technical knowhow (extension services) thereby increasing productivity of soya bean production within the study sites. Membership of cooperative society was not significant because majority $(70 \%)$ of the interviewees were not members of any group/cooperative society. Nevertheless, interviewees who were members of cooperative society were more technically-efficient in soya bean farming within the study sites, so membership did matter.

Both the transport-costs and distances to the soya bean market showed negative effects on technical-inefficiency indicating that a decline in technical-inefficiency as smallholders engaged in transporting the produce from farms to homesteads and finally to the market. The two factors were statistically significant at $5 \%$ level of probability when considered over time (Table 5). Cost of transportation of agricultural produce from the farm to the store and market had a great impact on production and income of smallholders. This was true because market was identified by interviewees as the greatest constraint in the study sites (Figure 3). These results concur with Buckmaster (2012) who showed that as distance to the main road increased, the likelihood of agricultural produce for sale in the market decreased. Households far away from a main road were less likely to produce for sale but for their subsistence. The overall results also concur with those of Shalma (2014) on technical-efficiency in soya bean production as found in Nigeria.

\subsubsection{Allocative efficiency}

From the estimated variance parameters for the stochastic-frontier cost-function (Table 6) for soya bean production in Western Kenya, the $Y$ coefficient of 0.9456 implied that about $95 \%$ of the variations in the total-cost of soya bean production in the study sites was due to differences in their cost-efficiencies. It was statistically significant at $1 \%$ level of probability that fulfilled the assumption of the model from economic theory. This meant that cost-inefficiency effects made significant contributions to the cost of soya bean production in the study area. Hence, the hypothesis that the parameter estimate of $Y=0$ was rejected. Therefore, the null hypothesis that the inefficiency effects (producers' socio-economic features do not influence the technical and allocative efficiencies) were absent from the model, was strongly rejected. The hypothesis test was confirmed using 
the Log likelihood-ratio test (Table 6), which showed the estimated value of -98.81 exceeding the $\chi^{2}$ critical value at $1 \%$ level of probability with number of restriction (df) of $11, \chi^{2}(1 \%, 11)$ and was 8.67 , indicating the presence of allocative-inefficiency.

The coefficients for the production factors (farm-size/land, seeds, fertiliser, agrochemical and labour) and soya bean output all were positively signed and statistically significant as per the $t$-ratios and $p$-values (Table 6). All these variables had direct-effect on cost-allocation and were very important in soya bean production. The cost of these production factors implied that an increase in cost of these factors increased total-cost of soya bean production in the study sites. An increase of $1 \%$ in the cost coefficient of these factors would have a commensurate impact on the allocativeefficiency of these factors (Table 6). The estimated soya bean output coefficient $(0.15)$ with positive sign signified that soya bean output increased the TC by $0.15 \%$. This increase showed that the TC was highly influenced by soya bean output realised by smallholders. The purpose of soya bean production was to maximise profit from sale of soya bean outputs. This was in tandem with the findings of Biam and Tsue (2013) who found that labour positively affected the total cost of producing soya bean and that smallholders could not maximise profits since their technical and allocative efficiency had not yet been achieved, which endangered sustainable food-security in Nigeria.

As for the inefficiency model coefficients, that for education level had a negative sign and was statistically significant (Table 6). The negative sign implied this variable had a significant effect on cost-allocation of interviewees under study and meant that when the educational level of the interviewees increased, allocative-inefficiency reduced. Smallholders with higher educational levels would allocate their input cost more efficiently than those with lower levels. These findings were in tandem with the a priori expectation that educational level affected farm financial-planning, which in turn always affected cost-efficiency. It improved technologies' adoption, decision-making on outputcost-allocation and brought about smallholders' financial understanding of the farming enterprise. This concurs with Dogbe et al. (2013) that showed that smallholders in Ghana undertook soya bean production due to financial gains expected from the enterprise. The parameter for household-size had a negative sign, which suggested a negative effect on allocative-inefficiency of the interviewees. Households with higher number of people were more cost-efficient than those with fewer people. This was because the former households provided cheaper labour force (with little/no-payment) than the latter who had to use hired-labour. Age was negatively-signed and not significant, suggesting older smallholders were more efficient than younger ones in soya bean cultivation within the study sites. The negative sign also implied a relationship of negative effect on costallocation of older smallholders. The younger soya bean smallholders were energetic and their involvement in soya bean enterprises meant allocative-efficiency would rise thereby reducing $\mathrm{TC}$ of soya bean production while increasing profitability. Both farmingexperience and gender-factor coefficients were negatively-signed and statistically significant, suggesting a negative effect on allocative-inefficiency thus exhibiting negative relationship with allocative-inefficiency (Table 6). Farming-experience influenced allocative-efficiency because of the accumulation of skills over-time by experienced smallholders, while gender-factor ensured equity and equality in resource access and use, control, and decision-making on the soya bean production and sharing of benefits. 
The parameters of credit, extension-services, membership, transport-costs and distance to markets were negatively-signed and not statistically significant except transport costs and distance to the markets (Table 6). This implied positive effect on costefficiency of soya bean producers in the study sites. Accessing credit led to efficiency in cost-allocation by smallholders and vice versa. The credit acquired enhanced adoption of technologies and empowered smallholders to buy the needed inputs on time. However, the three factors that were not significant factors, it was possibly due to diverting acquired credit to unintended uses; limited/absent visits from extension-staff and less membership to farmer-groups/cooperatives where only $30 \%$ were members. Membership to the organisations enhanced smallholders' access to credit-facilities and these organisations were a medium of ideas' exchange and sharing, which improved soya bean production activities. A $1 \%$ increase of these variables meant that cost-efficiency increased by the farmer saving on the TC incurred for the soya bean production. This study findings were in tandem with Nzima and Dzanja (2015), and Shalma (2014) in their studies on allocative-efficiency of soya bean markets in Malawi and Nigeria respectively, who found that cost-efficiency for soya bean production increased due to credit, and extension services availability.

\subsubsection{Economic efficiency}

The EE in agricultural production showed the welfare and the economic status of the interviewees (Table 7). It was the product of TE and AEs. The $\sigma^{2}$ obeyed the expectation of the data fitting into the stochastic-frontier as informed by economic theory. The $\mathrm{Y}$ coefficient (0.92) was positive and significant that lay between 0 and 1 as expected from economic theory. This implied that about $92 \%$ of the variations in the economic status of the soya bean smallholders were due to differences in their EEs. Economic-inefficiency significantly contributed to soya bean production in the study sites. Hence, the hypothesis that $\mathrm{Y}=0$ (there was no economic inefficiency) was rejected. The production variables (land, amount of seed, fertiliser, labour and agrochemicals), some were positively-signed and vice versa (Table 7). Farm-size, seed and fertiliser revealed positive effect on EE of the interviewees. This implied that an increase of $1 \%$ in the use of these variables resulted in an improvement to EE-status of the interviewees. Increasing soya bean cropland and application of fertiliser in soya bean production led to increased output visa-vis incomes of the interviewees that translated into improved-livelihoods. Both agrochemical and labour were negatively-signed, suggesting a negative effect on EE of the interviewees. This meant that increasing use of these two factors in soya bean production by $1 \%$, led to decreased EE. However, the negative-sign was against a priori expectation that could have arisen from inappropriate use of the inputs by the interviewees. Although all the other production variables were significant at various levels of probability, fertiliser was not because of its ability to fix atmospheric nitrogen into the soil. Seven of the inefficiency model coefficients (education-level, householdsize, farming-experience, gender-factor, credit, extension-services and distance to the market) were negatively-signed and significant to economic-inefficiency as per the $\mathrm{t}$ ratios and $p$-values (Table 7). This suggested that an increase in these variables reduced economic-inefficiency. However, three of these inefficiency model coefficients (age, transport-costs and membership), though were also negatively-signed, they were not significant as per the t-ratios and p-values (Table 7). The negative-sign indicated that a unit increase in the value of these variables led to a unit increase in EE corresponding to the coefficients of those variables. Age was not significant suggesting it did not really 
matter in terms of efficiency. Farming-experience exerted more influence on efficiency than age. Membership was not significant because majority $(70 \%)$ of the interviewees were not members of groups/cooperative societies.

The overall distribution of interviewees' TE showed a minimum of $11 \%$ and a maximum of $88 \%$ with a mean efficiency of $78 \%$ (Table 8 and Figure 4). The estimated mean TE of the interviewees indicated that soya bean smallholders in the study sites had $14 \%$ chance for improving production efficiency using the existing technology of the efficient smallholder. Hence, there was need to increase production by using available resources to attain the best frontier level. About $61 \%$ of the interviewees fell between technical-efficiency of $0-40 \%$. Interviewees operating at TE of $41-60 \%$ were $16 \%$ while interviewees with $\mathrm{TE}>60 \%$ were $23 \%$. This revealed that there was room for improvement since most $(77 \%)$ smallholders had TE of $<60 \%$. Evidently, if the average technically-efficient smallholder in the target sample was to achieve the TE position of the most-efficient smallholders, then the average technically-efficient smallholders could attain a $12 \%$ cost-savings $\{1-(78 / 88)\}$. On the contrary, the least-efficient smallholders could save a cost of $88 \%\{1-(11 / 88)\}$ if the same level of TE with the technicallyefficient interviewees were attained. The $\mathrm{AE}$ among the interviewees ranged from 10$90 \%$. The AE mean, minimum and maximum values were $65 \%, 10 \%$ and $90 \%$ respectively (Table 8). This showed a wide-spread of AE among the interviewees, though, none of the interviewees had attained the cost-frontier level of $100 \%$. The mean $\mathrm{AE}$ of $65 \%$ implied that there was a $35 \%$ shortfall in $\mathrm{AE}$ of an average smallholder. Interviewees that allocated the cost-resources of $0-40 \%$ were $49 \%$ of the sample, whereas $21 \%$ of the interviewees allocated cost-resources of $41-60 \%$, while those with an $\mathrm{AE}$ of $>60 \%$ were $30 \%$. The $\mathrm{EE}$ (a product of TE and $\mathrm{AE}$ ) showed that the average EE-level was about $59 \%$, with a minimum of $2 \%$ and a maximum of $86 \%$. With this, the most economically-inefficient smallholder could gain an EE of $98 \%\{1-(2 / 86)\}$ while if the average EE-operator in the target sample was to achieve the EE-level of the most economic-efficient smallholder, $30 \%$ of the total-cost would be saved. The results of this study concur with the findings of Nzima and Dzanja (2015) and those of Shalma (2014) undertaken in Malawi and Nigeria respectively, both of which showed that an increase in these variables reduced economic-inefficiency.

\subsection{Profitability and gross-margin analyses of soya bean production}

The interviewees affirmed that soya bean as a cash crop and food crop, compared to other crops grown in the study sites was both profitable and beneficial (Table 9 and Figure 5). There was high variability of profitability among smallholders in the five sub counties/divisions covered. When asked why it was beneficial, the interviewees gave various reasons (Figure 5). They alleged that it improved the healthy status especially of those who had arthritis and were asthmatic. Constant consumption of soya bean and its products had improved their status. Soya bean was a weed killer because a number of smallholders attested that before they started growing soya bean on their farms, the farms were full of striga and maize hardly did well on such farms. However, the growing of soya bean had improved such farms by eliminating striga weed and improving maize yields. Some smallholders because they believed soya bean was profitable, had over time abandoned certain crops that they used to grow earlier and had replaced those crops with soya bean growing. They also had future plans of expanding both acreage under soya bean production and to increase yield on average by over $230 \mathrm{~kg}$ accordingly. The results 
concur with the findings of Biam and Tsue (2013) and Collombet (2013) a studies undertaken in Nigeria and Western Kenya that showed soya bean production by smallholder producers was a profitable enterprise.

\section{Conclusion and recommendations}

Invariably, there were opportunities for boosting soya bean production in Western Kenya to ensure enhanced food/nutrition security and household incomes. However, there were constraints and as clearly demonstrated, market was the main constraint in soya bean production in the study sites, where its production could improve farmer incomes and sustain the production system. Nevertheless, soya bean production was not only limited by market access and information but also low yield due small parcels of land devoted to soya bean production, lack of credit facilities required for expansion of soya bean production and low levels of efficiency among the smallholders. Low production was also related to agronomic practices, such as late planting and poor disease management as well as low usage of yield improving inputs such as inoculum. Due to low production, smallholders tended to have small quantities to sell and the earliest opportunity smallholders had to turn their produce into cash was when the prices were the lowest in the marketing season during harvest time. The market constraint made the smallholders ignore or carelessly engaged in production of the crop in consequent years once they were unable to sell what they had produced in the current year. Soya bean production remained low despite its clear benefits for smallholders as the study has shown. This made soya bean an unattractive crop for smallholders as they lacked inputs, expertise and a market. There was need for future intervention either by county governments or other soya bean promoting organisations to improve smallholders' ability to add value and seek market information on available markets for soya bean and its products. There was also need for more county governments' investment in the smallholder soya bean seed production and multiplication by working hand in hand with research organisations and seed companies. Smallholders needed to be aware on the benefits of using inoculum and how to apply it in soya bean production as well as improve the extension service with regard to agronomic practices. Training smallholders on market identification and negotiation skills may help overcome marketing constraints.

\section{References}

Adeola, S.S., Omolohin, R.A., Ben Ahmed, and Adeneji, O.B. (2011) 'Socio-economic determinants of insecticide usage in cowpea production in Kaduna State, Nigeria', Journal of Agriculture and Social Research, Vol. 11, No. 1, pp.1-7.

Ahmadu, G.O.E. (2011) Socio-economic Factors Influencing the Level of Rural Youth Involvement in Cassava Production Activities in Benue State, Unpublished MSc Thesis, Ahmadu Bello University, Zaria.

Bekabil, U.T. (2015) 'Empirical review of production, productivity and marketability of soybean in Ethiopia', International Journal of $u$ - and e-Service, Science and Technology, Vol. 8, No. 1, pp.61-66.

Biam, C.K. and Tsue, P.T. (2013) 'Profitability of soybean-production by small holder farmers in Nigeria: a guide for sustainable food security', European Journal of Business and Management, Vol. 5, No. 30, pp.89-96. 
Buckmaster, A.D. (2012) Going the Distance: The Impact of Distance to Market on Smallholders Crop and Technology Choices, Unpublished MSc Thesis, The Virginia Polytechnic Institute and State University, Blacksburg, VA.

Castillo, J.J. (2009) Systematic Sampling. Available online at: http: //www.experiment-resourc es.com/systematic-sampling.html (accessed on 12 March 2016).

Chianu, J., Ajani, O.I.Y. and Chianu, J.N. (2008) 'Livelihoods and rural wealth distribution among farm households in Western-Kenya: implications for rural development, poverty alleviation interventions and peace', African Journal of Agricultural Research, Vol. 3, No. 7, pp.455-464.

Chianu, J., Vanlauwe, B., Mukalama, J., Adesina, A. and Sanginga, N. (2006) 'Farmer evaluation of improved soybean varieties being screened in five locations in Kenya: implications for research and development', African Journal of Agricultural Research, Vol. 1, No. 5, pp.143-150.

Chianu, J.N., Ohiokpehai, O., Vanlauwe, B., Adesina, A., De Groote, H. and Sanginga, N. (2009) 'Promoting a versatile but yet minor crop: soybean in the farming systems of Kenya', Journal of Sustainable Development in Africa, Vol. 10, pp.324-344.

Collombet, R.N. (2013) Investigating Soybean Market Situation in Western-Kenya: Constraints and Opportunities for Smallholder Producers, Unpublished minor thesis in Plant Production Systems: PPS-80424, Wageningen University.

Dogbe, W., Etwire, P.M., Martey, E., Etwire, J.C., Inusah, I., Baba, Y. and Siise, A. (2013) 'Economics of soybean-production: evidence from Saboba and Chereponi Districts of Northern Region of Ghana', Journal of Agricultural Science, Vol. 5, No. 12, pp.38-46.

Doss, C.R. (2006) 'Understanding farm level technology adoption: lessons learnt from CIMMYT's micro-survey in Eastern Africa', CYMMIT Economic Working, Mexico, D.F., pp.7-30.

FAO (2011) The State of Food and Agriculture 2010-11. Women in Agriculture: Closing the Gender Gap for Development, Rome.

FAO (2014) The State of Food and Agriculture: Innovations in Family Farming, Rome.

GoK (Government of Kenya) (2010) Economic review of agriculture 2010, Central Planning and Project Monitoring Unit (CPPMU), Government Printers, Nairobi, Kenya.

Idrisa, Y.L., Ogunbameru, B.O. and Amaza, P.S. (2010) 'Influence of farmers' socio-economic and technology characteristics on soybean seeds technology adoption in Southern Borno State, Nigeria', African Journal of Agricultural Research, Vol. 5, No. 12, pp.1394-1398.

ITC (International Training Centre) (2009) Training Module: Introduction to Gender Analysis and Gender-sensitive Indicators, Gender Campus, International Training Centre of the International Labour Organisation, Turin, Italy. Available online at: http://www.gender matters.eu (accessed on 20 June 2016).

Jaetzold, R., Schmidt, H., Hornet, Z.B. and Shisanya, C.A. (2006) Farm Management Handbook of Kenya. Natural Conditions and Farm Information, Vol. 11/C, 2nd ed., Ministry of Agriculture/GTZ, Nairobi (Western Province).

James, C. (2014) Global Status of Commercialized Biotech/GM Crops: 2014, ISAAA Brief No. 49, ISAAA, Ithaca, NY.

Keane, J. (2008) A 'New' Approach to Global Value Chain Analysis, Working Paper 293, Overseas Development Institute, London.

Koskei, R.C., Tabu, I.M., Cheruiyot, E. and Langat, J.K. (2013) 'Ensuring food security in commercialised farming: a case of smallholder tea farmers in Bureti district, Kenya', African Crop Science Conference Proceedings, Vol. 11, pp.563-567.

Kumar, G. (2007) 'Soybean can help fight dreaded HIV', Bio Screening Industry News, Asia, HIV Research, Press Releases, Allahabad University.

Lubungu, M., Burke, W. and Sitko, N.J. (2013) Challenges of Smallholder Soybean-production and Commercialization in Eastern Province of Zambia, Policy Brief No. 62, Indaba Agricultural Policy Research Institute (IAPRI), Lusaka, Zambia. 
MoDP (Ministry of Devolution and Planning) (2013) Kakamega and Busia County Development Profiles, May 2013, Kenya Vision 2030-Towards a Global Competitive and Prosperous Kenya, Government Printers, Nairobi, Kenya.

Myaka, F.A., Kirenga, G. and Malema, B. (Eds) (2005) Proceedings of the First National Soybean Stakeholders Workshop, 10-11 November, Morogoro, Tanzania.

NEPAD (2013) African Agriculture, Transformation and Outlook, AU-NEPAD, South Africa.

Nzima, W.M and Dzanja, J. (2015) 'Efficiency of soybean markets in Malawi: structure, conduct and performance approach', International Journal of Business and Social Science, Vol. 6, No. 4, pp.162-170.

Olorunsanya, E.O., Babatunde, R.O., Orebiyi, J.S. and Omotosho, J.O. (2009) 'Economic analysis of soybean-production in Kwara State, North Central Nigeria', Global Approaches to Extension Practice, Vol. 5, No. 2.

Onyibe, J.E., Kamara, A.Y. and Omoigui, L.O. (2006) Guide to Soybean Production in Borno State, International Institute of Tropical Agriculture, Ibadan.

Rachier, G.O. (2001) 'An overview of soybean (Glycine max L.) production and research in Western-Kenya', Paper presented to Soybean Project in Kakamega District Launching Workshop, KARI-Kakamega.

Ragasa, C. and Golan, J. (2012) The Role of Rural Producer Organizations for Agricultural Service Provision in Fragile States, International Food Policy Research Institute (IFPRI), Washington, DC.

Shalma, H.J. (2014) Economic Analysis of Soya Bean Production under Sasakawa Global 2000 Project in Kaduna State, Nigeria, Unpublished MSc Thesis, Ahmadu Bello University, Zaria, Nigeria.

Thagana, W.M. and Riungu, T.C. (2000) 'The status of Kenya in the global production and supply of oilseeds and oilseed products', Proceedings of the 7th KARI Scientific Conference, KARI Headquarters, 12-16 November, pp.197-201.

Tinsley, R.L. (2009) Assessing the Soybean Value Chain Analysis in Kenya, CNFA Farmer to Farmer Program, November-December 2009, Colorado State University, Fort Collins, Colorado.

Udoh, E.J. and Akintola, J.O. (2001) Land Management and Resource Use Efficiency among Farmers in South-Eastern Nigeria, Elshada Global Ventures, Ibadan. 